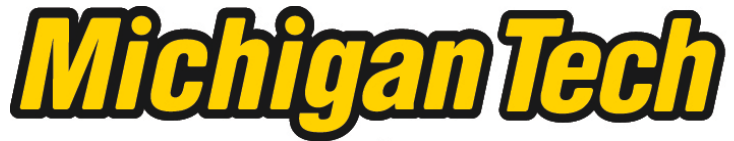 \\ Michigan Technological University Create the Future Digital Commons @ Michigan Tech
}

Dissertations, Master's Theses and Master's Reports - Open

Dissertations, Master's Theses and Master's

Reports

2011

Life cycle assessment of trayless dining

Nawaf Isam Blaisi

Michigan Technological University

Follow this and additional works at: https://digitalcommons.mtu.edu/etds

Part of the Civil and Environmental Engineering Commons

Copyright 2011 Nawaf Isam Blaisi

\section{Recommended Citation}

Blaisi, Nawaf Isam, "Life cycle assessment of trayless dining ", Master's Thesis, Michigan Technological University, 2011.

https://doi.org/10.37099/mtu.dc.etds/223

Follow this and additional works at: https://digitalcommons.mtu.edu/etds

3 Part of the Civil and Environmental Engineering Commons 


\title{
LIFE CYCLE ASSESSMENT OF TRAYLESS DINING
}

\author{
By \\ Nawaf Isam Blaisi
}

\begin{abstract}
A THESIS
Submitted in partial fulfillment of the requirements for the degree of MASTER OF SCIENCE (Environmental Engineering)

MICHIGAN TECHNOLOGICAL UNIVERSITY

2011

(C) 2011 Nawaf Isam Blaisi
\end{abstract}


This thesis "Life Cycle Assessment of Trayless Dining," is hereby approved in partial fulfillment of the requirements for the degree of MASTER OF SCIENCE IN ENVIRONMENTAL ENGINEERING.

Department of Civil and Environmental Engineering

Signatures:

Thesis Advisor

Dr. Christopher L Wojick

Department Chair

Dr. David Hand

Date 


\section{Table of Contents}

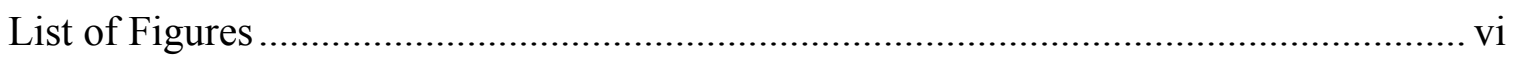

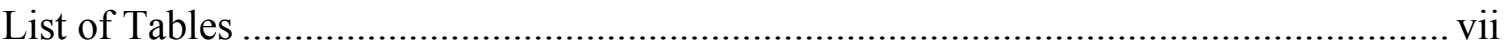

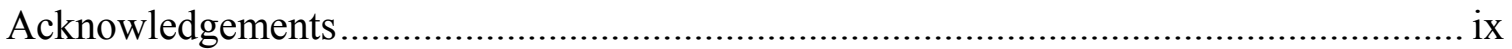

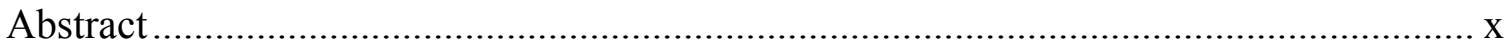

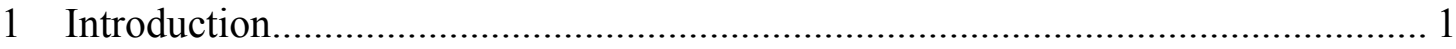

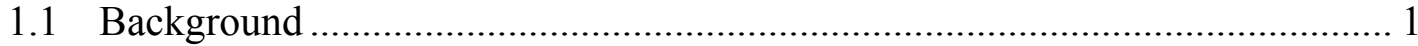

1.2 Previous Studies conducted on trayless dining ............................................ 2

1.2.1 Studies on Resource Consumption....................................................... 2

1.3 History of Trayless Dining at Michigan Tech University .................................. 3

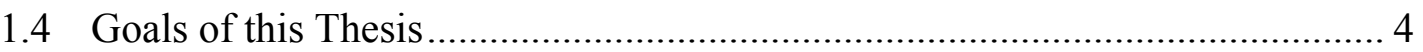

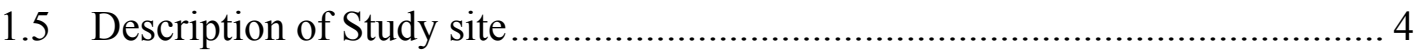

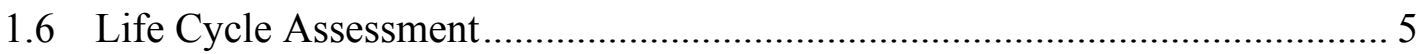

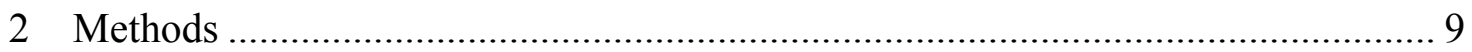

2.1 Introduction and Experiment Design ............................................................ 9

2.1.1 Tableware and Trays ............................................................................ 11

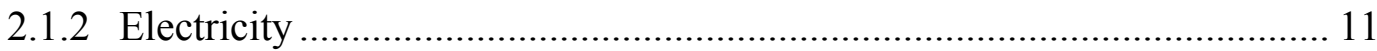

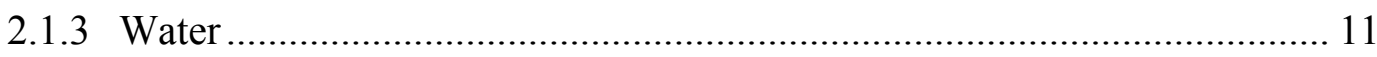

2.1.4 Food Consumption and Waste ………………..................................... 11

2.1.5 Steam Measurements ……………………….................................... 12

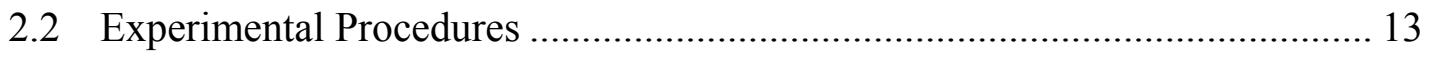

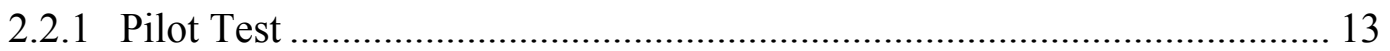

2.2.2 Determine Optimum Length for Full Scale Experiment............................ 14

2.2.3 Full-Scale Experiment...................................................................... 15 
2.2.4 Life Cycle Assessment and Cost............................................................. 16

2.2.4.1 Identifying the Inventory Data …………………………………..... 16

2.2.4.2 Determine the life cycle impact/cost assessment of life cycle inventory

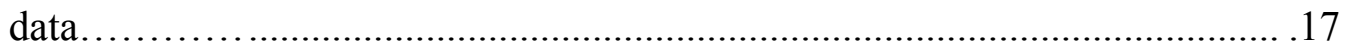

2.2.4.3 Interpreting the results of life cycle impacts assessment..................... 18

2.3 Limitations and Assumptions.................................................................... 18

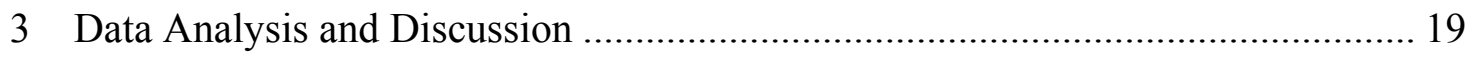

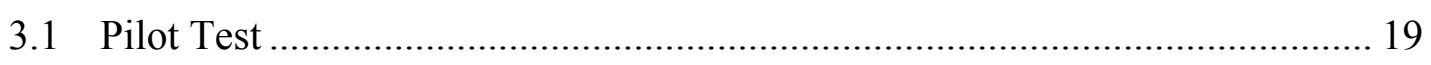

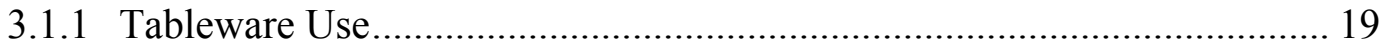

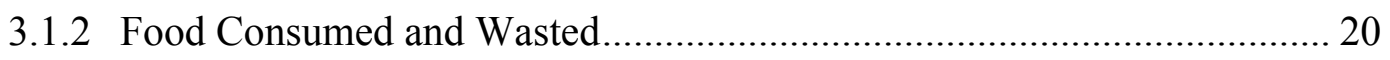

3.1.3 Water, Electricity, and Steam Consumption ............................................ 22

3.2 Determining Optimum Length for the Full-Scale Experiment ......................... 24

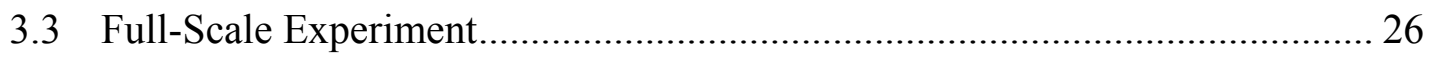

3.3.1 Dinner Plates and Dishwashing Glass Rack ............................................. 27

3.3.2 Food Waste from Pre-rinse and Pan Washing Area................................... 28

3.3.3 Food Prepared, Unserved, and Consumed ………………......................... 31

3.3.4 Dishwashing Machine Water Consumption................................................ 33

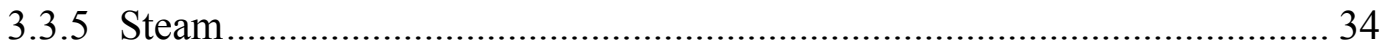

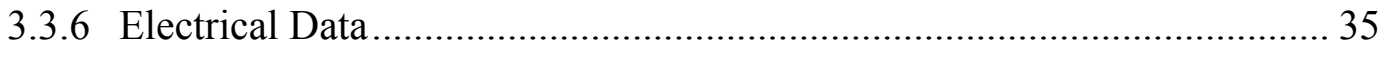

3.4 Life Cycle Cost Analysis ............................................................................... 36

3.5 Environmental Impact Analysis .................................................................... 37

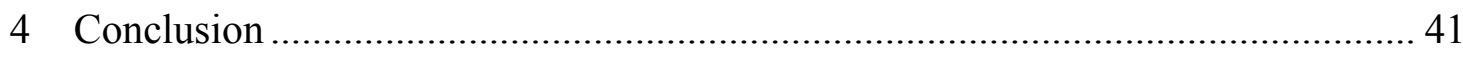

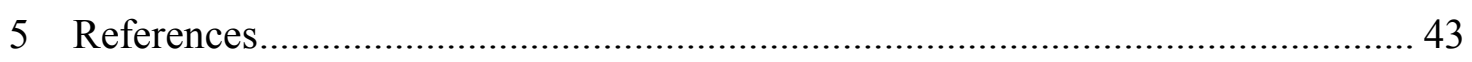

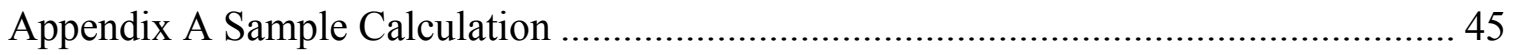


Appendix B Pilot and Full Scale Experiment Raw Data

Appendix C SimaPro Software Parameters Description ............................................ 50

Appendix D Survey of Students Attitudes for Trayless Dining ..................................... 51 


\section{List of Figures}

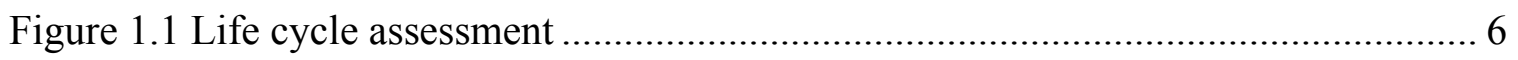

Figure 1.2 General system boundary for the study …….................................................. 7 


\section{List of Tables}

Table 2.1 Changed parameters.............................................................................. 10

Table 3.1 Count of tableware and number of diners during the first pilot test ................ 19

Table 3.2 Data for food prepared, served, consumed, and waste from the first pilot test 21

Table 3.3 Water, electricity, and steam consumption for the second pilot test ................ 22

Table 3.4 Sample size determination for the full-scale experiment................................. 25

Table 3.5 Number of diners during the full-scale experiment ....................................... 27

Table 3.6 Dinner plates used during the full-scale experiment ………………….......... 27

Table 3.7 Dishwashing glass rack used during the full-scale experiment ........................ 28

Table 3.8 Food waste from the pre-rinse area for the full-scale experiment .................... 29

Table 3.9 Food waste from the pan washing area for the full-scale experiment .............. 30

Table 3.10 Prepared food for the full-scale experiment …………………………….... 31

Table 3.11 Unserved food for the full-scale experiment ................................................ 32

Table 3.12 Food consumed results for full-scale experiment ............................................ 32

Table 3.13 Dishwasher machine water consumption for the full-scale experiment ......... 34

Table 3.14 Steam consumption in the full-scale experiment........................................... 35

Table 3.15 Dishwasher electrical consumption data for the full-scale experiment .......... 36

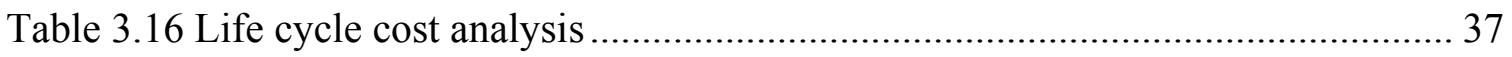

Table 3.17 Environmental impact analysis by using the IPCC 2007 GWP 100a method 38

Table 3.18 Environmental impact analysis by using the cumulative energy demand

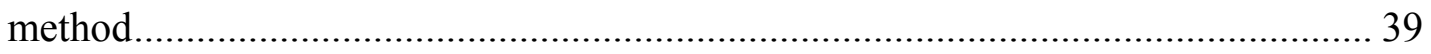

Table B. 1 Second pilot test water consumption raw data ............................................... 47

Table B.2 Second pilot test electrical consumption raw data ....................................... 48 
Table B. 3 Full-scale experiment dishwashing machine electrical consumption raw data

Table B. 4 Full-scale experiment water consumption raw data.................................. 49

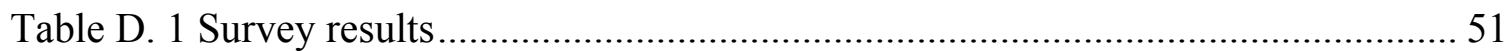




\section{Acknowledgements}

To my God: Thank you for giving me the faith.

To King Abdualah AlSoud: God bless you.

To my Advisor, Dr. Christopher Wojick: Thank you so much. I will remember your advice throughout my life. Without your support and encouragement, I would not have become a better engineer.

To my committee member, Dr.David Shonnard and Dr. Neil Hutzler: Thank you for your advice.

To the Green Campus Enterprise: Thank you for helping me out in this project.

To my father and mother: Thank you so much for your support.

To my Wife, Haton Fuad Khayat: "Behind every successful man is a woman, behind her is his wife," Groucho Marx 


\begin{abstract}
Universities in the United States are applying more sustainable approaches to their dining service operations. "The increase in social consciousness and environmental stewardship on college campuses has spurred an array of new and innovative sustainability programs"(ARAMARK Higher Education 2008). University residence dining is typically cafeteria style, with students using trays to carry food. Studies report that food served without trays substantially reduces food waste and water and electrical consumption associated with washing trays. Commonly, these reported results are estimates and not measurements taken under actual operating conditions.

This study utilizes measurements recorded under actual dining service conditions in student residence halls at Michigan Technological University to develop the following: 1) operational-specific data on the issues and potential savings associated with a conversion to trayless dining and 2) life cycle assessment (LCA) cost and environmental impact analyses comparing dining with and without trays. For the LCA, the entire life cycle of the system is considered, from the manufacturing to the usage and disposal phases.
\end{abstract}

The study shows that trayless dining reduces food waste because diners carry less food. The total savings for the diner shifts when not using trays for the standard academic year (205 days), with an average number of 700 diners, is 7,032 pounds of food waste from the pre-rinse area (33\% reduction) and 3,157 pounds of food waste from the pan washing area (39\% reduction). In addition, for each day of the study, the diners consumed more food during the trayless portion of the experiment. One possible explanation for the increased food consumption during this short duration study could be that the diners found it more convenient to eat the extra food on their plate rather than carrying it back for disposal. The trayless dining experiment shows a reduction in dishwasher water, steam, and electrical consumption for each day of the study. The average reduction of dishwasher water, steam, and electrical consumption over the duration of the study were $10.7 \%, 9.5 \%$, and $6.4 \%$ respectively. Trayless dining implementation would result in a decrease of 4,305 gallons of consumption and wastewater discharge, $2.87 \mathrm{~mm}$ BTU of steam consumption, and $158 \mathrm{kWh}$ of electrical 
consumption for the dinner shift over the academic year. Results of the LCA indicate a total savings of $\$ 190.4$ when trays are not used during the dinner shift. Trayless dining requires zero $\mathrm{CO}_{2}$ eq and cumulative energy demand in the manufacturing stage, reductions of $1005 \mathrm{~kg} \mathrm{CO}_{2}$ eq and $861 \mathrm{MJ}$ eq in the usage phase, and reductions of 6458 $\mathrm{kg} \mathrm{CO} 2$ eq and $1821 \mathrm{MJ}$ eq in the end of the life cycle. 


\section{Introduction}

\subsection{Background}

Universities in the United States are applying more sustainable approaches to their dining service operations. "The increase in social consciousness and environmental stewardship on college campuses has spurred an array of new and innovative sustainability programs" (ARAMARK Higher Education 2008). The environmental performance of dining services is also increasing worldwide due to the administrators and students' positive attitudes toward the environment. A high percentage of students reside on campus and eat in campus dining halls (Upcraft and Schuh 1996), so increasing the sustainability of these operations could result in significant savings.

Dining service providers at universities are implementing green initiatives, such as biofuel generation from used cooking oil, food composting, trayless dining, recycled napkins, green chemicals, among others. University residence dining is typically cafeteria style with students using trays to carry food. Studies have shown that serving food without trays substantially reduces food waste and consumption and water and electrical consumption associated with washing trays; based on published data, a number of universities are implementing trayless dining.

The most commonly referenced study by ARAMARK provides substantive data on food waste reduction, but their estimates for other types of savings, e.g., water and electricity are questionable. For example, "ARAMARK determined that on average, a tray conservatively requires one-third to one-half gallon of water to wash" (ARAMARK Higher Education 2008). There may be little or no correlation between how much water it takes to wash a tray and the savings realized in dining operations. In addition, the director of Dining Services at Michigan Technological University, Robert Hiltunen, has attended many food service conventions. According to him, many attendees quoted the same results and figures for water savings, which came from the ARAMARK study (Hiltunen 2009). The only way to obtain accurate values for water savings is to physically measure water consumption under actual cafeteria conditions. In addition, none of the studies utilized life cycle analysis (LCA) to determine the overall costs of dining with trays and without trays. The other studies provide general details on dining operations, but fewer 
details on the type of machine, number of diners, type of food served, and other factors. This study utilizes measurements recorded under actual dining service conditions. For the LCA, the entire life cycle of the system will be considered, including the manufacturing, usage, and disposal phases.

This study will provide a valuable comparison of the environmental impacts of dining with and without trays, but the results cannot be generalized to all cafeteria dining operations. The dishwasher in this study was the conveyer type with autosense rinse and an autostop conveyer. (With autosense rinse, water only sprays when dishes are passing through the dishwashing machine, and with autostop, the conveyer stops if no dishes are loaded for a five-minute period). If the dishwasher is a batch or conveyer type of dishwasher without autosense rinse and autostop features, the actual change in water and electricity use could vary widely. Nevertheless, because conveyer type dishwashers with autosense and autostop are common in large university dining service operations, the results will be broadly applicable. Even operational differences, such as the number of diners at the institution or the type of food served, could affect realized water and electricity use per diner, but these variations would generally not be significant. Michigan Tech Dining Services supported this study to provide definitive data for the University's dining operations.

\subsection{Previous Studies Conducted on Trayless Dining}

\subsubsection{Studies on Resource Consumption}

Trayless dining studies have been reported by several dining service companies, such as ARAMARK, Bon Appétit, and by universities, such as American University and Purdue University. However, these studies were not comprehensive in accurately measuring all changes. Most studies concentrated on electricity, water, or waste savings.

For example, Bon Appétit, a dining management company provider for many universities in the U.S., conducted an experiment to determine the feasibility of trayless implementation at St. Joseph's College in Maine. The study showed a 20\% reduction in total waste, which would result in significant reductions of methane generation for the land-filled waste (Bon Appétit 2009). American University conducted a trayless dining study in one of its dining halls (Terrace Dining Room), which showed a reduction in 
waste and dish use during trayless dining. This study recommended implementation of trayless dining at American University (Sobecki 2009).

\subsection{History of Trayless Dining at Michigan Tech University}

In the fall semester of 2009, dining services at Michigan Technological University introduced and implemented trayless dining every Tuesday in its three residence halls: Wadsworth, McNair, and Douglass Houghton. However, because of adverse student reactions, such as diners throwing food on the floor, and harassment of the dining hall workers, the experiment was quickly discontinued.

ARAMARK Higher Education, a dining service provider, released a study on the social aspects and barriers to implementing trayless dining (ARAMARK Higher Education 2008). Information in this study is useful in understanding the students' reactions. Some common recommendations for implementing trayless dining are to start at the beginning of school year and provide students with information on the advantages of going trayless.

Subsequent to the fall 2009 experiment, the director of dining facilities at Michigan Tech, Mr. Robert Hiltunen, asked the Green Campus Enterprise to study the feasibility of implementing trayless dining in the residence halls during the spring 2009 semester. At Michigan Tech, students can enroll in "enterprise" classes that function as a consulting company to work on a project for a client. The Green Campus Enterprise works to reduce the University's carbon footprint, and it was well positioned to take on this project. The Green Campus students began work on the project by studying trayless implementation at other universities and surveying students in each of the Michigan Tech's dining halls regarding their opinions on trayless dining. (See Appendix D for further information on the survey.) One of the universities contacted for information on their previous trayless implementation was Grand Valley State University. Using information provided by Grand Valley and the data obtained from the surveys, the Green Campus students made the following recommendations to Mr. Hiltunen regarding trayless dining implementation:

1.) Widely publicize the change to trayless and provide students with data on why trayless dining makes sense. 
2.) Conduct an actual experiment at Michigan Tech comparing dining with trays and without trays.

3.) Initiate the trayless dining program at the start of a new academic year.

4.) As indicated in the survey, student reactions to trayless dining are favorable, with the overall survey results indicating that $31 \%$ of respondents were in favor of a complete switch to trayless, $23 \%$ of the respondents were in favor of trayless sometimes, and $46 \%$ responded they did not want to go trayless.

5.) There is no need to change the standard tableware currently used at Michigan Tech when switching to trayless dining.

Mr. Robert Hiltunen accepted the recommendations, including the suggestion to conduct the experiment at Michigan Tech. The decision was made to conduct the project as part of a master's thesis. Mr. Robert Hiltunen will use the results of this experiment in deciding whether to implement trayless dining at the University.

\subsection{Goals of this Thesis}

A variety of goals of this thesis relate to environmental issues, but two primary goals exist. One can be generalized to a wide variety of educational and non-educational institutions and the other is specific to Michigan Tech as follows:

1. Conduct a life cycle assessment (LCA) and cost analysis of trayless and tray dining. The results of this study can be utilized by a broad range of educational and non-educational institutions to facilitate decisions related to green dining.

2. Provide Michigan Tech dining services with data specific to their operations, which can be used to make a determination regarding trayless dining implementation.

\subsection{Description of Study Site}

There are three main residence halls at Michigan Tech, Wadsworth, McNair, and Douglas Houghton, each with an integral dining facility. Based on recommendations by dining service director Mr. Robert Hiltunen, Wadsworth Hall was chosen as the optimum study site. Wadsworth Hall is the largest dining hall on campus and receives the largest 
number of diners. During the trayless dining experiment, all dining halls at Michigan Tech were trayless, but the measurements were taken only at Wadsworth Hall during the dinner shift. The hours of operation of the Wadsworth Hall dinner service shift typically started Monday through Friday at 4:00 p.m. and ended at 6:30 p.m., and Saturday and Sunday the hours were from 4:00 p.m. to 7:30 p.m.

Food prepared in the Wadsworth Hall kitchen is served cafeteria style with students returning dishes to a centralized wash location. Once the dirty dishes enter the wash area, they are manually pre-rinsed and then loaded in the dishwashing machine. The dishwashing machine is a Hobart model PTM-824BD-7-8-9. The machine is a conveyer style machine with autosense rinse and autostop features. The autosense only sprays water when dishes are loaded into the dishwashing machine. When the dishwasher is idle (no dishes are loaded), the conveyer and pumps automatically shut off.

\subsection{Life Cycle Assessment}

According to Allen and Shonnard, products, services, and processes all have a life cycle. For products, the life cycle begins when raw materials are extracted or harvested. Raw materials then go through a number of manufacturing steps until the product is delivered to a customer. The product is used, then disposed of or recycled" (Allen and Shonnard 2002). Figure 1-1 shows the life cycle stages in which emissions and wastes are generated and raw materials and energy are consumed. 


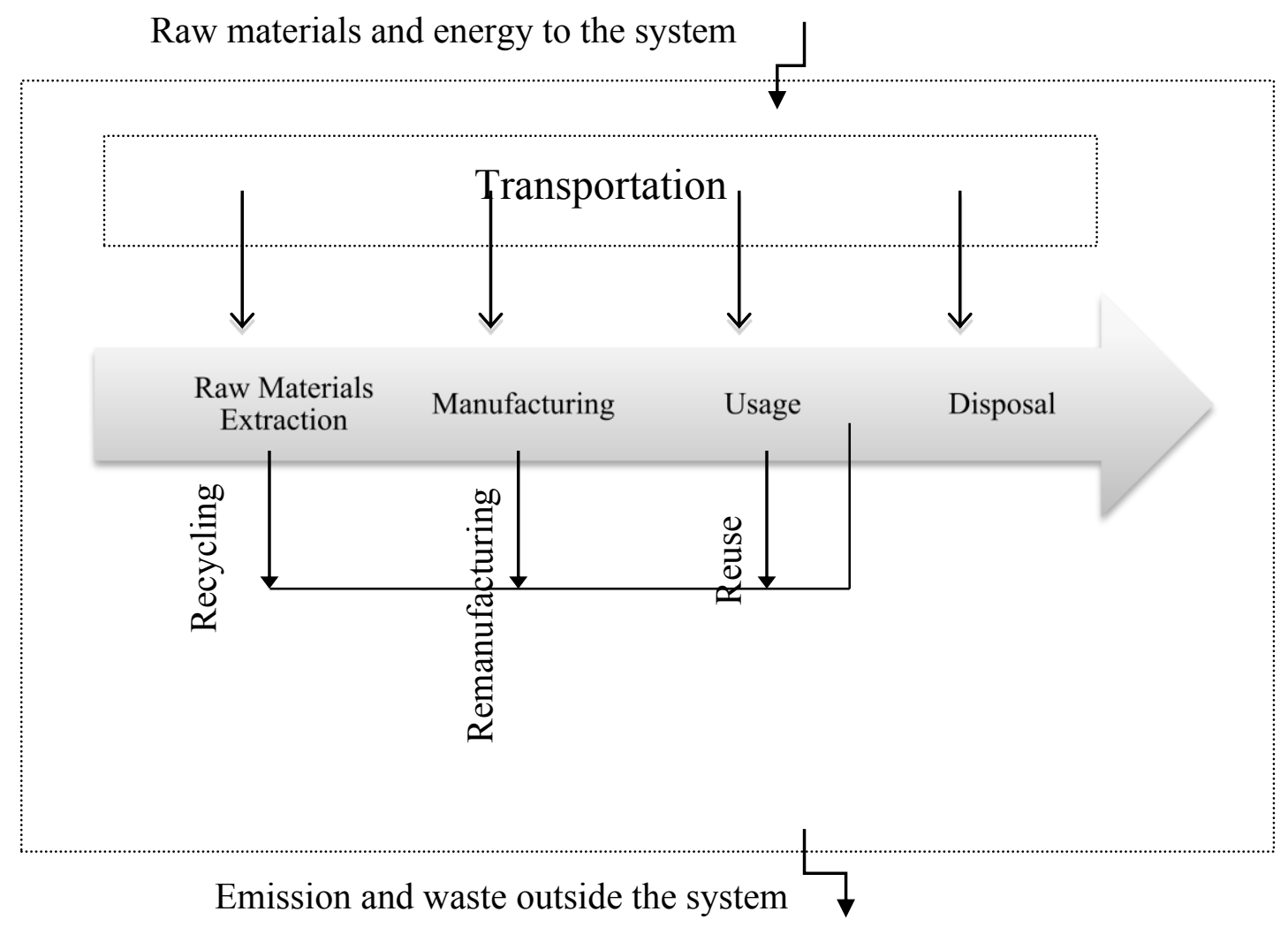

Figure 1.1: Life cycle assessment

With LCA studies there are four main steps to the process (Allen and Shonnard 2002):

1. Defining the goals and boundaries of the experiment and identifying the functional unit;

2. Identifying the inventory data;

3. Assessing life cycle impacts; and

4. Interpreting the results of life cycle impacts assessment.

Step 1 is defining the goal, boundary condition, and functional unit. The goal of this study is to compare the life cycle costs of dining with and without trays and to provide decision makers with a planning tool related to trayless dining. The boundary condition is defined as - simply the limits placed on data collection for the study"(Allen and Shonnard 2002). The system boundary for this study encompassed the dishwashing area at Wadsworth Hall dining operation. Data used in the LCA was a limited set of the 
inputs and outputs from this system. This study conducted a limited life cycle assessment and did not account for all the inputs and outputs from the dining hall. This study will account for the most important parameters that had significant changes in values. For example, the electricity needed to light the entire dining hall is the same when dining with trays or without trays, so the LCA was accounted for it. Figure 1-2 illustrates the general system boundary for this study. The green dotted line is the system boundary for this study. Inputs and outputs to the system are indicated by arrows entering or exiting the system respectively.

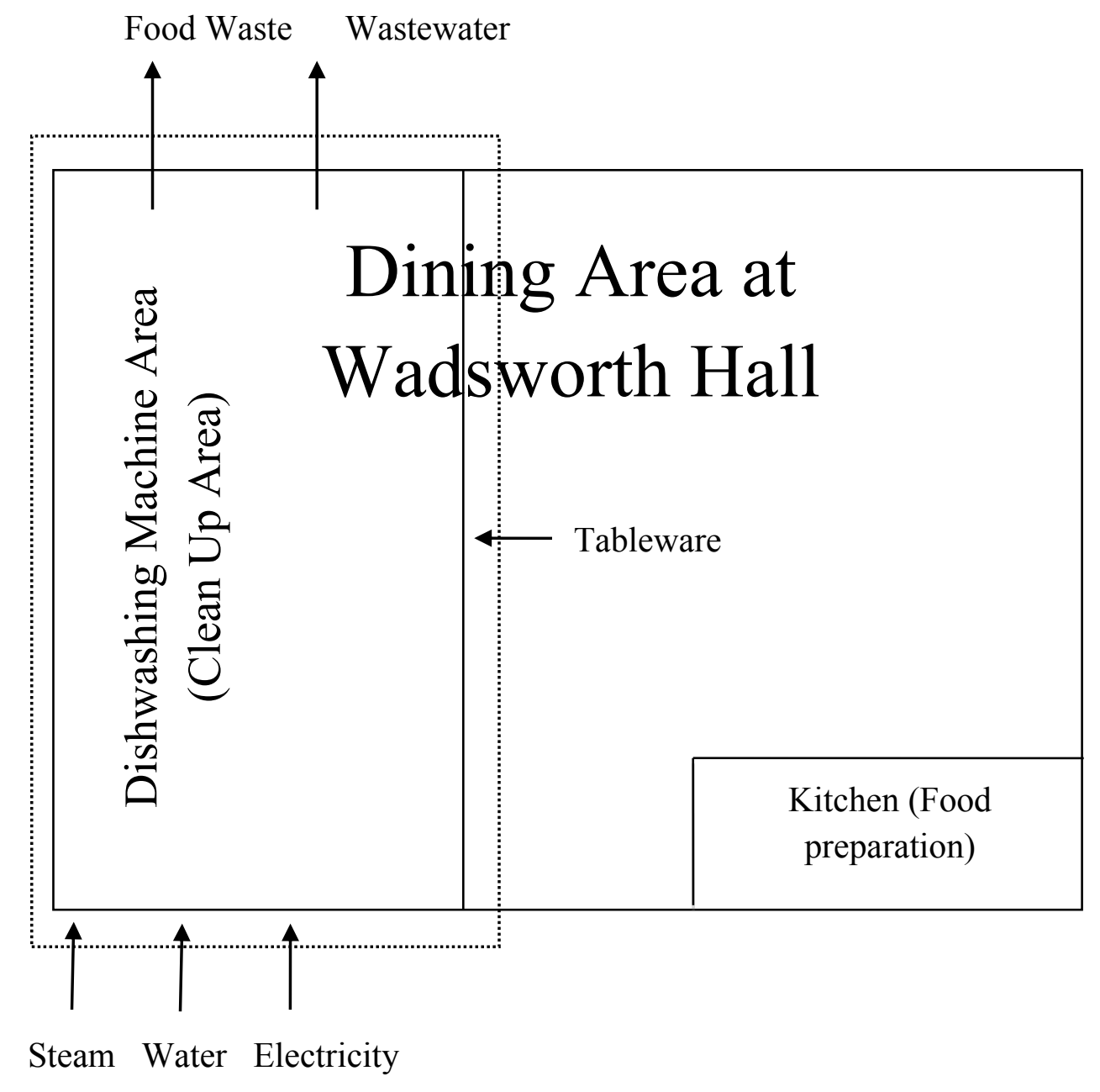

Figure 1.2: General system boundary for the study 
Further, it is important to define the functional unit of this experiment. The functional unit can be defined as the service delivered by the product system, which in this case is one dinner meal.

Step 2 is identifying the inventory data. The inventoried data are the inputs (e.g., dishes and water consumption) and the outputs (e.g., food waste) for the system.

Step 3 "in a life cycle assessment is to assess the environmental impacts of the inputs and outputs compiled in the inventory" (Allen and Shonnard 2002).A computer program was used to assess the environmental impact analysis, which will be discussed further in the method section below.

Step 4 is to interpret the results of life cycle impacts assessment. "It comprises of three main elements:

- Identification of the significant issues based on the results of the LCI and LCIA phases of a LCA.

- Evaluation of results, which considers completeness, sensitivity, and consistency checks.

- Conclusions and recommendations.

The aim of the interpretation phase is to reach conclusions and recommendations in accordance with the defined goal and scope of the study. Results from the LCI and LCIA are combined together and reported in order to give a complete and unbiased account of the study. The interpretation is to be made iteratively with the other phases" (Tosca 2011). 


\section{Methods}

\subsection{Introduction and Experiment Design}

During the initial planning and execution phases, meetings were held with Robert Hiltunen, the Michigan Tech director of dining services, and William Hall, the associate director of residential dining. The meetings were conducted to identify the dining facility's expectations for the project, to analyze relevant aspects of the dining operations, to obtain input on the timing and design of the project, and to discuss funding for instrumentation required to run the tests.

The data required to address the dining facilities' expectations for the project, as identified in these meetings, closely paralleled the data needed to develop the LCA. Developing the LCA of dining with and without trays and developing data specific to Michigan Tech to assess trayless dining implementation were previously identified in the Introduction section as primary goals 1 and 2. Data required to achieve goals 1 and 2 are similar and consist of dining operations parameters expected to change when switching to trayless dining. For example, water consumption for the dishwashing machine would be expected to change, but the power required to light the dining area would not change. Both of these cross the LCA system boundary, but because the power to run the lights will not change, it is not measured or considered in the LCA. Values for the parameter that change (hereafter "changed parameters") will be measured during dining service operations with and without trays for use with the LCA, goal 1, and to develop the Michigan Tech specific data, goal 2. In collaboration with dining services personnel, a comprehensive listing of changed parameters was identified. Along with identifying these parameters, a technique for measuring each parameter was developed. Table 2.1 identifies the changed parameters, the method for measuring each parameter, and the timing of these measurements. 
Table 2.1

Changed parameters

\begin{tabular}{|c|c|c|}
\hline $\begin{array}{l}\text { Changed } \\
\text { Parameters }\end{array}$ & Measurement Procedures & Timing \\
\hline Number of Diners & $\begin{array}{l}\text { At the end of each dinner shift, one of the dining hall } \\
\text { supervisors supplied the data. }\end{array}$ & $\begin{array}{l}\text { Number of diners } \\
\text { was recorded } \\
\text { based on the } \\
\text { number of swipe } \\
\text { cards. }\end{array}$ \\
\hline $\begin{array}{l}\text { Tableware and } \\
\text { Trays }\end{array}$ & $\begin{array}{l}\text { All counting was by hand tally counters. Counts were } \\
\text { taken at } 30 \text {-minute intervals until the end of the shift. For } \\
\text { more details refer to the next section. }\end{array}$ & $\begin{array}{l}\text { Start: beginning } \\
\text { of dinner service } \\
\text { End: when } \\
\text { workers finished } \\
\text { cleaning dishes. }\end{array}$ \\
\hline Food waste & $\begin{array}{l}\text { Food waste was measured by weighing the waste } \\
\text { receptacle bags. For more details refer to the next } \\
\text { section. }\end{array}$ & $\begin{array}{l}\text { When workers } \\
\text { finished cleaning } \\
\text { dishes }\end{array}$ \\
\hline $\begin{array}{l}\text { Amount of food } \\
\text { consumed }\end{array}$ & $\begin{array}{l}\text { The following equation was used to determine the } \\
\text { consumed food in pounds } \\
\text { Consumed food = prepared food - unserved food - waste } \\
\text { food. } \\
\text { For more details refer to the next section. }\end{array}$ & $\begin{array}{l}\text { When dining } \\
\text { services stopped } \\
\text { serving students }\end{array}$ \\
\hline $\begin{array}{l}\text { Table cleaning and } \\
\text { amount of water in } \\
\text { wash } \\
\text { buckets(buckets } \\
\text { are filled with } \\
\text { water to clean the } \\
\text { dining hall tables) }\end{array}$ & $\begin{array}{l}\text { Buckets were assigned to the worker with a known } \\
\text { volume. Each time the worker fills the bucket, he/she } \\
\text { recorded the filling time with the assigned volume. }\end{array}$ & $\begin{array}{l}\text { When dining } \\
\text { services stopped } \\
\text { serving students }\end{array}$ \\
\hline Floor cleaning & $\begin{array}{l}\text { The crew supervisor recorded time for each worker and } \\
\text { provided data. }\end{array}$ & $\begin{array}{l}\text { When dining } \\
\text { services stopped } \\
\text { serving students }\end{array}$ \\
\hline Electricity & $\begin{array}{l}\text { Electrical meters installed in dining and dishwashing } \\
\text { area. Details are provided in subsequent section }\end{array}$ & $\begin{array}{l}\text { Start: beginning } \\
\text { of dinner service } \\
\text { End: when } \\
\text { workers finished } \\
\text { cleaning dishes. }\end{array}$ \\
\hline Water & $\begin{array}{l}\text { Water meters were installed in dishwashing area. Details } \\
\text { provided in the subsequent section. }\end{array}$ & $\begin{array}{l}\text { Start: beginning } \\
\text { of dinner service } \\
\text { End: when } \\
\text { workers finished } \\
\text { cleaning dishes. }\end{array}$ \\
\hline $\begin{array}{l}\text { Steam to heat the } \\
\text { water }\end{array}$ & $\begin{array}{l}\text { Details on procedures are provided in the subsequent } \\
\text { section. }\end{array}$ & $\begin{array}{l}\text { Start: when } \\
\text { serving students } \\
\text { in the dinner shift } \\
\text { End: when } \\
\text { workers finished } \\
\text { cleaning dishes. }\end{array}$ \\
\hline
\end{tabular}




\subsubsection{Tableware and Trays}

The tableware and trays were counted using hand tally counters as the items were loaded into the dishwashing machine. Subtotals were recorded at 30-minute intervals. Two people were involved in the counting procedure; one counting the tableware items and the other recording the time. The types of tableware, which were accounted for in this study are provided in sections 2.2.1 and 2.2.3.

\subsubsection{Electricity}

Two electricity meters were installed at Wadsworth Hall for continuous reading of electricity consumption. One meter (Veris Industries model 8036) measured the electricity for the entire dining area, and the other meter (Veris Industries model 8035) measured the electrical consumption of the dishwasher. The meters stored the $\mathrm{kWh}$ readings at 15-minute intervals in digital files that were later accessed later to determine the electrical consumption during the dinner shift.

\subsubsection{Water}

Three water meters were installed at Wadsworth Hall to measure the dishwasher's cold water consumption (Badger Meter Model RCDL 70), hot water consumption (Badger Meter Model RCDL 70), and pre-rinse area consumption (Badger Meter Model RCDL 25). A single meter was used in the pre-rinse area to measure the mixed (hot and cold) water. The meters readings were recorded manually at 30 minutes intervals.

The dishwashing machine tanks were drained at the end of each meal and filled prior to the next meal. Fill volume for the tanks was 120 gallons; therefore, a total of 360 gallons were used to fill the tanks each day. The fill volume was not considered in this study because the same procedure was followed with and without trays.

\subsubsection{Food Consumption and Waste}

Wadsworth Hall uses self-serve cafeteria style dining. This study measures only the quantities of main dish items. Main dish items for each day are identified as a footnote in the results section. Side dish food items from the salad bar, dessert area, 
beverage area, the self-cooking area, and french fries and hamburgers were excluded from the food measurement because they represent only a small portion of the food consumption and waste by diners (Hiltunen 2009). Main dishes in Wadsworth Hall are served in pans. The workers weighed the food in two sample serving pans for each main dish item, and the average of these values was used in calculating the total amount served for each main dish item. Unused pans of main dish food items were refrigerated for later use. At the end of the dinner shift, food from partially full pans was discarded. In addition, the shift manager prepared a production sheet after each dinner that provided data on the weight of each main dish prepared and the amount refrigerated for later use.

The two sources of food waste are uneaten food that the students return to the dishwashing area, and unserved food remains from empty and partially empty serving pans. The two sources of food waste were measured using a scale. The weight of the main dish consumed food was calculated using the following equation:

Consumed Food (lbs) = Prepared Food (lbs) - Unserved Food (lbs) - Waste Food (lbs)

Discards of the side dishes (e.g., hamburgers and french fries) were included in the total weight of the waste food, but they were not included in the weight of the prepared or the unserved food. Because the measured waste food included some contribution from side dishes, the previous equation underestimated the actual quantity of main dish consumed food.

\subsubsection{Steam Measurements}

Steam, generated at the natural gas fired central heating plant, is used for heating domestic water at Wadsworth Hall. Energy losses associated with water heating arise from the generation of steam from natural gas, heat loss through steam piping from the central heating plant, and heating the water with steam. This study does not account for these losses. Steam consumption to heat water for the pre-rinse and washing machine can be determined using Equation 2: 
Steam Consumption $=$ Gallons of Water Consumed $* \frac{8.43 \text { Ibs }}{\text { gallon }} * \frac{\left(\text { Temperature }_{\text {final }}-\text { Temperature }_{\text {Initial }}\right)}{1,000,000}$

where the steam consumption is in units of mmBTU (one million BTUs). The water consumption was determined from the dishwasher water meter readings in gallons. The initial temperature was taken in degrees Fahrenheit directly from the tap water using a thermometer. The final temperature was taken in degrees Fahrenheit directly from the dishwashing machine's water temperature display.

\subsection{Experimental Procedures}

The procedures for this experiment can be broken down into four main phases as follows:

1. Pilot test.

2. Determine optimum length for full-scale experiment.

3. Full-scale experiments.

4. Life Cycle Assessment and cost analysis.

\subsubsection{Pilot Test}

A pilot test was conducted first to assess the selected measurement protocols, such as the counting methods for tableware and trays and metering of water and electrical consumption, and to obtain data used to determine the optimal length for the full-scale experiment. The pilot test was conducted at the diner shift for five days (Tuesday, October 26, through Saturday, October 30, 2010) under normal operating conditions, i.e., trays were used. These five days were selected because they were typical dining days with no breaks or vacation days. The students were not aware of the pilot test because it occurred during normal operating conditions and the individuals performing the counting were in the enclosed dishwashing area. Changed parameters measured during the pilot were those listed previously in Table 2.1. For tableware, the following were counted: trays, dinner plates, 10-oz. bowls, 12-oz. bowls, salad bowls, dessert plates, dishwasher glass racks (each rack holds 25 glasses), ketchup plates, and cereal bowls. 
Two of the changed parameters identified previously in Table 2.1-time and amount of water for table cleaning and time for floor cleaning-were not measured during the pilot test. These two parameters were omitted because the floor and tables must be cleaned whether the floor is clean or not, and the time taken to clean floor and table were the same as the regular dining days.

During the pilot test, a malfunctioning valve in the dishwasher resulted in erroneous water consumption readings. This necessitated a second pilot test during the dinner shift for seven days (Tuesday, December 7, through Monday, December 13, 2010) to obtain dishwasher consumption data. This second test measured only water, steam, and electrical consumption.

\subsubsection{Determine Optimum Length for Full-Scale Experiment}

A statistical approach was used to determine the minimum number of days the full-scale experiment (with and without trays) could be run to provide accurate results. The method selected for this analysis involved the use of an online statistics calculator (Dimension Research 2005) to determine the confidence interval around the mean. Data input to the calculator were as follows: 1) the sample size, 2) the mean of the sample, 3 ) the standard deviation of the sample, and 4) the selected confidence level (90\%). The mean and standard deviation, calculated using Microsoft Excel, associated with data measured during the pilot tests for each of the changed parameters listed in Table 2.1were input to the calculator and the sample size (number of days to run the full-scale experiment) was adjusted until an appropriate confidence interval around the mean was obtained. The confidence interval was considered appropriate when the upper and lower range for the true population mean (i.e., mean + confidence interval value and mean) were within the range $0.9 *$ mean and $1.10 *$ mean. For example, if the calculated upper range for the true population mean of a particular parameter was more than $1.10 *$ the mean, then the sample size (number of days to run the full-scale experiment) would be increased.

Because data recorded during the pilot test was unique to each changed parameter, these statistical analyses yielded a range of values for the minimum days to run the full-scale experiment. Values for the number of days to run the experiment, 
tabulated in the results section, ranged from three days to more than 150 days. A meeting was scheduled with representatives of Michigan Tech Dining Services to discuss the duration of and to select dates for the full-scale experiment. Because of practical limitations on the length of the trayless portion of the full-scale experiment, the Dining Services representatives were asked to identify the changed parameters that they deemed significant for the experiment. Those selected were water and electricity consumption, food consumed, and the number of trays and dinner plates used. For the changed parameters of interest to Dining Services, the minimum length of time to run the experiment was six days, and this met the time limitations for the trayless portion imposed by Dining Services.

\subsubsection{Full -Scale Experiment}

The full-scale experiment was conducted at Wadsworth Hall dining area during the dinner shift for two six-day periods. Tuesday, February 15, through Sunday, February 20,2011 , were the dates of the first portion of the experiment, with trays, and Tuesday, March 29, through Sunday, April 3, 2011, were the dates of the trayless portion of the experiment. The selected dates represent typical dining days, i.e., no special student events or breaks were scheduled. Further, the same main dishes were served on the corresponding days for the tray and trayless portions of the experiment. Based on the results of the pilot tests, measurements were recorded for only a subset of the changed parameters identified in Table 2.1.

Measurements were recorded for electricity, steam, and water consumption for dishwashing, food preparation, food waste, and cleaning of trays, dinner plates, and glassware. Measurement procedures for these parameters followed the protocols used during the pilot tests.

Meetings were held with Dining Services personnel to plan other aspects of the full-scale experiment. During the first portion of the full-scale experiment, i.e., with trays, standard dining practices were followed, so no special planning was needed. For the trayless portion of the experiment, plans were developed for informing the students in advance, minimizing negative reaction from the students, and conducting operations at the two other University residence hall dining facilities. Prior research (see the social 
analysis section in Appendix D) indicated that the best approach in changing to trayless operations was to inform the students in advance regarding why the change was being made and to do so in a conspicuous manner. Dining Services followed this advice and advertised the trayless portion of the full-scale experiment with large posters and flyers identifying the need for the experiment and explaining its limited duration

Some adverse reactions from students regarding tray removal were anticipated, so in an effort to minimize those reactions, an ice cream social was held at the conclusion of the experiment to thank students for their cooperation. The site for this experiment was Wadsworth Hall dining area, but during the trayless portion of the experiment, trays were also removed from the dining facilities at the two other University residence halls. The same posters and flyers were displayed at all three dining halls, but the students were not informed that measurements were being taken only at Wadsworth Hall.

\subsubsection{Life Cycle Assessment and Cost}

The typical phases for an LCA were discussed in the previous Introduction Section. The goals, functional unit, and boundary of the experiment were identified and discussed in Section 1.6. For the reader's convenience, the system boundary and functional unit identified previously are redefined here. The system boundary for this study will encompass the dishwashing area at Wadsworth Hall dining operation. The functional unit is defined as one dinner meal served. Therefore, for the LCA, the values measured in the experiments for changed parameters were normalized by the number of diners.

\subsubsection{Identifying the Inventory Data}

For this step, the inputs and outputs to the system are identified and quantified. As this is a limited LCA, only a subset of the inputs and outputs to the system are considered. The inputs to the system measured in the full-scale experiment consist of electricity, steam, and water consumption for dishwashing, and trays, dinner plates and glassware used. Prepared and consumed food was measured during the full-scale experiment, but these data were analyzed to inform Dining Services. Prepared and 
consumed food does not cross the system boundary, so it will not be included in the LCA. The outputs from the system are food waste and wastewater.

Related information for these data inputs and outputs include the primary constituents in the fuel mix to generate the electricity are coal $69.4 \%$, and nuclear $23.9 \%$ (UPPCO 2011); tap water is the dishwashing water source; the tray material is fiberglass (Cambro Manufacturing Company 2011); and the plate material is fiberglass (Carlisle FoodService Products 2011). The weight of the trays and plates were determined using a laboratory balance.

\subsubsection{Determine the Life Cycle Impact/Cost Assessment of Life Cycle Inventory Data}

All of the inventory results data were grouped into different environmental impact categories, such as global warming and the cumulative energy demand, using SimaPro software (Product Ecology Consultants 2010). SimaPro software was utilized to run the environmental impact analyses. The environmental impacts of each inventory element were quantified using the impact assessment tools, including the IPCC 2007 GWP 100a and Cumulative Energy Demand (CED), which are available in SimaPro. IPCC 2007 GWP 100a was used to determine the total green house emissions with a unit of $\mathrm{kg} \mathrm{CO}_{2}$ eq. The life cycle impacts assessment consists of manufacturing, usage, and end life cycle phases. The manufacturing phase of this study includes raw materials, electricity, air emissions, and water emissions associated with the manufacturing of the trays and plates. The usage phase of this study includes the water and electrical consumption, and steam consumption for the dishwashing machine. The end of the life cycle impact analysis includes the wastewater and food waste.

In addition to the LCA, dining services requested a cost analysis. This analysis considered the purchase cost of the trays and the usage cost for water, electricity, and steam consumed. The purchasing cost of the trays was provided by the Associate Director of Dining Services (Hall 2011).The electricity, water, and steam billing rates for Michigan Tech were provided by the University Energy Manager (Taivalkoski 2010). 


\subsubsection{Interpreting the Results of Life Cycle Impacts Assessment}

Recommendations and suggestions will be provided to the decision makers through combining the results of the inventory analysis and the life cycle impact/cost assessment.

\subsection{Limitations and Assumptions}

1. This study considers only the electrical consumption for the dishwashing machine. Electricity to run the kitchen was not included because electricity consumed by other devices, e.g. lighting, within the system boundary is independent of tray use.

2. Forks, spoons, and knifes were not counted because their use was considered independent of tray use and because of the difficulty in obtaining an accurate count.

3. Only a small fraction of students use coffee cups, so they were not included.

4. A small quantity of dirty dishes from the previous shift (prior to dinner) was held over to the dinner shift. These dishes and the related water and electricity consumption were not measured for this experiment.

5. The quantity of prepared food reported in this study was for main dishes only. Side dishes were ignored because they represent only a small portion of the food consumption and waste by diners. Food not considered included the salad bar, dessert food, beverages, french fries, hamburgers, and food prepared in the self-cooking area. The same main dish items were served for corresponding days of the tray and trayless experiments to provide a consistent basis for comparison. 


\section{Data Analysis and Discussion}

\subsection{Pilot Test}

Pilot tests were conducted to assess the selected measurement protocols and to determine the optimal length for the full-scale experiment. The first pilot test was conducted in Wadsworth Hall dining area during the diner shift for five days (Tuesday, October 26, through Saturday, October 30,2010). Due to a malfunctioning valve on the dishwashing machine, a second pilot test was required to measure water and electricity consumption. This test was conducted during the dinner shift for seven days (Tuesday, December 7, through Monday, December 13, 2010). This section will address the results from the pilot tests, including the count of the tableware used, the number of diners, food consumption and waste, and water and electrical consumption.

\subsubsection{Tableware Use}

Table 3.1 shows the tableware count and the number of diners for each day of the first pilot test.

Table 3.1

Count of tableware and number of diners during the first pilot test

\begin{tabular}{|l|c|c|c|c|c|}
\hline & Tuesday & Wednesday & Thursday & Friday & Saturday \\
\hline Trays & 733 & 850 & 821 & 694 & 593 \\
\hline Dinner plates & 789 & 913 & 1116 & 795 & 720 \\
\hline 10 oz bowls & 154 & 52 & 112 & 35 & 106 \\
\hline 12 oz bowls & 93 & 80 & 116 & 122 & 56 \\
\hline Salad bowls & 398 & 487 & 440 & 413 & 283 \\
\hline Dessert plates & 303 & 265 & 109 & 216 & 170 \\
\hline $\begin{array}{l}{ }^{1} \text { Dishwashing glass } \\
\text { rack }\end{array}$ & 40 & 52 & 37 & 41 & 31 \\
\hline Catsup plates & 33 & 133 & 15 & 89 & 172 \\
\hline Cereal bowls & 33 & 35 & 30 & 35 & 20 \\
\hline \# of diners & 720 & 715 & 828 & 773 & 570 \\
\hline $\begin{array}{l}\text { Notes: } \\
{ }^{1} \text { Each dishwashing glass rack contained 25 glasses. }\end{array}$ & & & \\
\hline
\end{tabular}

It is clear from Table 3.1 that, for most days, the number of trays and dinner plates used closely parallels the number of diners. Several possible explanations exist for 
variation in the number of trays and the number of diners shown for some days. At times, students only come to eat dessert or drink coffee, and they do not use a tray. In addition, Dining Services workers can eat in the cafeteria for free and are not counted in the number of diners. Finally, some students, who go back for a second serving, pick up a new tray.

For all days, the number of dinner plates used exceeds the number of diners, as well as the number of trays. It is not uncommon, depending on the main dish served that day, for a student to take more than one plate. During the full-scale experiment, it will be interesting to see if the ratio of dinner plates to diners changes.

For the other types of tableware, the number of plates and bowls used was much lower than the number of diners. Also for most of these items, a high degree of variability is shown in the number used across the five days of the test and a poor correlation exists between the number of these items used and the number of diners.

\subsubsection{Food Consumed and Wasted}

Table 3.2 provides data from the first pilot test on food preparation, consumption for the main dish items, and the amount of food waste. Also identified are the main dish items for each day of the test.

Dining Services provided data on the amount of prepared and unserved food, and using these values, the amount served was calculated. The food waste from pans is the food scraped out of the empty or partially empty pans by the food service workers. Food waste from the pre-rinse area is the uneaten food that students return to the dishwashing area. 
Table 3.2

Data for food prepared, served, consumed, and waste from the first pilot test

\begin{tabular}{|l|c|c|c|c|c|}
\hline & ${ }^{1}$ Tuesday & Wednesday & ${ }^{2}$ Thursday & Friday & Saturday \\
\hline Prepared food (lbs) & 485 & 500 & 1165 & 831 & 775 \\
\hline Unserved food (lbs) & 40 & 48 & 276 & 16 & 126 \\
\hline${ }^{3}$ Actual food served (lbs) & 445 & 452 & 889 & 815 & 649 \\
\hline $\begin{array}{l}\text { Food waste from pre- } \\
\text { rinse area (lbs) }\end{array}$ & 145.5 & 217 & 343 & 145 & 129 \\
\hline $\begin{array}{l}\text { Food waste from pans } \\
\text { washing area (lbs) }\end{array}$ & 46.5 & 60 & 42 & 45 & 50 \\
\hline${ }^{4}$ Consumed food (lbs) & 253 & 175 & 504 & 625 & 470 \\
\hline \# of diners & 720 & 715 & 828 & 773 & 570 \\
\hline
\end{tabular}

Notes:

${ }^{1}$ Main dish items for each day were:

- Tuesday: Milwaukee cod, mixed sausage grill, waffle fries, corn

- Wednesday: Chicken parmesan with meatballs, marinara sauce, garlic bread, sugar snap peas

- Thursday: Chicken hot wings, chili nachos, maggot casserole, spilled guts, and fresh corn ears

- Friday: Fish, BBQ pork chops, veggie dumplings, steak fries, mixed vegetable

- Saturday: Burger bar, wildfire wings, onion rings, and corn

${ }^{2}$ Thursday was a Halloween special dinner. The food names reflect the Halloween customs, such as maggot casserole and spilled guts.

${ }^{3}$ Actual served $=$ prepared food - unserved food.

${ }^{4}$ Consumed food $=$ prepared food-unserved food - food waste from pre-rinse area - food waste from pan washing area.

The amount (weight) of food prepared depends on the popularity of the main dish

and the inedible components. For example, on Thursday, the amount of main dish prepared was much greater than other days, but the chicken bones and corncobs, which are inedible, would add weight. Dining services uses data from previous consumption to determine the amount to prepare. Because of these differences in the amount of main dish prepared and served, it is important that the same main dishes be served on corresponding days of the tray and trayless full-scale experiment.

The weight of food waste from the pre-rinse area, show in Table 3.2, is the major constituent of total food waste. Because the students control how much is returned uneaten, analyzing whether the amount changes when switching from trays to trayless will prove interesting.

The consumed food shown in the table was calculated as served food minus the sum of the food waste from pans and pre-rinse. Because discards from the side dishes 
were included in the weight of the waste food, but not included in the weights of the prepared or the unserved food, the actual weight of consumed food would be greater than indicated in the table.

\subsubsection{Water, Electricity, and Steam Consumption}

Five meters were installed in the Wadsworth dining area to measure water and electricity consumption. Three water meters were installed on the dishwashing machine and the pre-rinse area. One electric meter measured consumption of the overall dining area and the second meter measured consumption of the dishwashing machine only. Because of the boundary condition selected for this study, only data for the dishwasher electrical consumption was used for this analysis. Steam generated on campus is used to heat the water. Steam consumption was calculated using measured water temperatures and the equation provided previously in the Method section above.

Table 3.3 shows the water, electricity, and steam consumption for the pre-rinse and dishwashing machine. The water and electricity consumption is the water and electricity meter reading at the end of the shift, minus the water and electricity meter reading at the start of the shift.

Table 3.3

Water, electricity, and steam consumption for the second pilot test

\begin{tabular}{|c|c|c|c|c|c|c|c|}
\hline & Tuesday & Wednesday & Thursday & Friday & Saturday & Sunday & ${ }^{2}$ Monday \\
\hline $\begin{array}{l}{ }^{3} \text { Pre-rinse } \\
\text { water (gal) }\end{array}$ & 12.6 & 7.9 & 18 & 8 & 13.1 & 24.2 & 36.5 \\
\hline $\begin{array}{l}{ }^{3} \text { Dishwashing } \\
\text { machine } \\
\text { water (gal) }\end{array}$ & 272 & 289 & 216 & 241 & 251 & 357 & 296.6 \\
\hline $\begin{array}{l}{ }^{3} \text { Electricity } \\
(\mathrm{kWh})\end{array}$ & 12.4 & 11.7 & 10.3 & 15 & 17.7 & 17.8 & 13.6 \\
\hline $\begin{array}{l}{ }^{1} \text { Steam } \\
(\mathrm{mmBTU})\end{array}$ & 0.20 & 0.21 & 0.16 & 0.18 & 0.19 & 0.27 & 0.22 \\
\hline \# of diners & 858 & 893 & 818 & 740 & 740 & 888 & 1154 \\
\hline $\begin{array}{l}\text { Notes: } \\
{ }^{1} \text { mmBTU stands } \\
{ }^{2} \mathrm{~A} \text { special dinner } \\
{ }^{3} \text { Raw data is pro }\end{array}$ & one million & $\begin{array}{l}\text { TUs. } \\
\text { is day, which }\end{array}$ & ounted fo & large & oer of dine & & \\
\hline
\end{tabular}

No direct correlation exists between the pre-rinse water consumption and the number of diners. For example, on Wednesday, the number of diners was 893 and pre- 
rinse area water consumption was 7.9 gallons, while on Thursday, more than twice the water was consumed but there were only 818 diners. The data for Sunday shows an even greater variation. Workers manually spray the dishes for the pre-rinse and the workers rotate shifts throughout the week. Observation of the pre-rinse process over the duration of the experiment indicated the large variation in consumption was due to differences in rinse styles. Some workers completely rinse the dishes, whereas others only partially rinse.

The dishwashing machine water and steam consumption shows a much better correlation to the number of diners. The only day with a significant variation is Sunday. In addition to dishes, cooking pans were also washed in the dishwasher and account for some of the water usage.

A noteworthy event regarding the operation of the dishwasher machine occurred on Thursday of the pilot test. On this day, the worker made a conscientious effort to load the dishwasher in a manner that would minimize water and electricity consumption. The worker loaded the machine fully and turned off the conveyer when no dishes were loaded. This practice yielded reduced consumption of water and electricity, but the consumption was not dramatically different from other days, e.g., Tuesday. The lack of variation can be attributed to the automatic features of the dishwashing machine, which shuts off the water and conveyer when no dishes are present in the machine. At no time during the full-scale experiment did a worker conspicuously try to minimize water and electricity use.

The dishwasher water consumption indicated in Table 3.3 only accounts for water used in the dishwashing process. The dishwashing machine tanks are drained at the end of each meal, and they are filled prior to the next meal. Fill volume for the tanks is 120 gallons, so a total of 360 gallons were used for tank filling each day. The fill volume was not considered in this study because the same procedure was followed with and without trays. 


\subsection{Determining Optimum Length for the Full-Scale Experiment}

A statistical calculator for the confidence interval around the mean was used to evaluate the minimum number of days required for the full-scale experiment. Data developed during the pilot experiments for food, tableware, electricity, and water were used in this analysis. A $90 \%$ confidence level and a range of $\pm 10 \%$ around the mean were used in the calculations. Details for the calculation method were provided previously in the Method section above. Table 3.4 provides the results of calculations for the minimum number of days to run the full-scale experiment for each of the parameters measured during the pilot tests. Values for the mean and standard deviation presented in the table were calculated by first normalizing the raw data for each day of the pilot test by the number of diners and then calculating the mean and standard deviation. For example, to calculate the mean and standard deviation for the trays in Table 3.4, the number of trays measured during each day of the first pilot test was divided by the corresponding number of diners (See Table 3.1). These normalized values for each day of the test were then averaged to develop the mean, and then the standard deviation was calculated. The raw data was normalized for two reasons: to provide better data consistency (lower values for standard deviation) and the functional unit defined previously in the methods section for the LCA is one dinner meal. 
Table 3.4

Sample size determination for the full-scale experiment

\begin{tabular}{|l|c|c|c|}
\hline & $\begin{array}{c}{ }^{2} \text { Standard } \\
\text { deviation } \\
\text { normalized } \\
\text { data }\end{array}$ & $\begin{array}{c}\text { Mean } \\
\text { normalized } \\
\text { data }\end{array}$ & $\begin{array}{c}\text { Number of days } \\
\text { required for full- } \\
\text { scale experiment } \\
\text { (days) }\end{array}$ \\
\hline Trays & 0.11 & 1.03 & 3 \\
\hline Dinner plates & 0.13 & 1.20 & 3 \\
\hline 10 oz bowls & 0.07 & 0.13 & 65 \\
\hline 12 oz bowls & 0.02 & 0.13 & 7 \\
\hline Salad bowls & 0.07 & 0.56 & 12 \\
\hline Dessert plates & 0.11 & 0.30 & 30 \\
\hline Dishwashing glass rack & 0.01 & 0.06 & 5 \\
\hline Catsup plates & 0.11 & 0.13 & $\begin{array}{c}\text { More than } 150 \\
\text { days }\end{array}$ \\
\hline $\begin{array}{l}\text { Cereal bowls } \\
\text { Pre-rinse area water }\end{array}$ & 0.01 & 0.04 & More than 150 \\
consumption (gal)
\end{tabular}

The number of days required for the full-scale experiment to obtain accurate data for the various parameters ranged from three days to more than 150 days. After developing these data, a meeting was held with representatives of Michigan Tech Dining Services to select the duration of the experiment. Due to practical limitations, Dining Services requested that the full-scale experiment be run for no more than one week.

The parameters meeting this criterion were trays, dinner plates, 12-oz. bowls, dishwashing glass racks, and dishwashing machine electrical and water consumption. In 
further discussions, Dining Services representatives indicated the following parameters were of significant interest for them in the full-scale experiment: water, steam and electricity consumption, food consumed and wasted, and the number of trays and dinner plates used. Based on the results of the statistical analysis and the input from Dining Services, the following parameters were selected for inclusion in the full-scale experiment: trays (during the portion of the experiment with trays), dinner plates, dishwashing glass racks, and dishwashing machine electrical, water and steam consumption, all of which met the one-week criteria, and food consumed and wasted, which were of interest to dining services.

\subsection{Full Scale Experiment}

The full-scale experiment was conducted at Wadsworth Hall dining area during the dinner shift for two six-day periods. Tuesday, February 15, through Sunday, February 20, 2011, were the dates of the first portion of the experiment, with trays, and Tuesday, March 29, through Sunday, April 3, 2011, were the dates of the trayless portion of the experiment. The dates selected were typical dining days, i.e., no special student events or breaks were scheduled. Further, the same main dishes were served on the corresponding days for the tray and trayless portions of the experiment.

An ice cream social was held at the end of the trayless portion of the experiment to thank the students for cooperation during the experiment. The head of Dining Services scheduled the social after the completion of the Sunday dinner service, but the ice cream was actually served during the meal. The extra dishes used with the ice cream could result in changes in values for some of the parameters measured, e.g., dishwasher water and electricity use, so the data for Sunday was not included in any of the overall calculations.

Table 3.5 shows the number of diners for the tray and trayless dining. Note the consistency in the number of diners for corresponding days of the tray and trayless experiment. 
Table 3.5

Number of diners during the full-scale experiment

\begin{tabular}{|l|c|c|c|c|c|c|}
\hline & Tuesday & Wednesday & Thursday & Friday & Saturday & Sunday \\
\hline Trays dining (\# diners) & 714 & 788 & 700 & 645 & 671 & 840 \\
\hline Trayless dining (\# diners) & 708 & 756 & 725 & 574 & 663 & 825 \\
\hline
\end{tabular}

\subsubsection{Dinner Plates and Dishwashing Glass Rack}

Table 3.6 and Table 3.7 show the dinner plates and dishwashing glass racks counted during the full-scale experiment. Both the total count and the ratio by diner are shown. Also included is the percentage change from tray to trayless with the calculations based on the ratio by diner.

Table 3.6

Dinner plates used during the full-scale experiment

\begin{tabular}{|c|c|c|c|c|c|}
\hline & \multicolumn{5}{|c|}{ Dinner plates } \\
\hline & \multicolumn{2}{|c|}{ Trays dining } & \multicolumn{2}{|c|}{ Trayless dining } & \multirow[b]{2}{*}{$\begin{array}{c}{ }^{1} \text { Percentage change } \\
\text { based on the ratio by } \\
\text { diner }(\%)\end{array}$} \\
\hline Days & Count & Ratio by diner & Count & Ratio by diner & \\
\hline Tuesday & 927 & 1.30 & 746 & 1.05 & -19.2 \\
\hline Wednesday & 951 & 1.21 & 832 & 1.10 & -9.1 \\
\hline Thursday & 928 & 1.33 & 1019 & 1.41 & 6.0 \\
\hline Friday & 814 & 1.26 & 694 & 1.21 & -4.0 \\
\hline Saturday & 826 & 1.23 & 793 & 1.20 & -2.4 \\
\hline${ }^{2}$ Sunday & 1058 & 1.26 & 886 & 1.07 & -15.1 \\
\hline $\begin{array}{l}{ }^{3} \text { Average } \\
\text { value }\end{array}$ & & 1.26 & & 1.17 & -7.1 \\
\hline \multicolumn{6}{|c|}{$\begin{array}{l}\text { Notes: } \\
{ }^{1} \text { Percentage change is calculated by (Ratio by diner trays dining - Ratio by diner trayless dining)/(Ratio by diner } \\
\text { trays dining) } * 100 \\
{ }^{2} \text { Sunday is excluded from the overall percentage change analysis because of the ice cream social. The ice cream } \\
\text { social was held at the conclusion of the experiment to thank the students for their cooperation. } \\
{ }^{3} \text { The averaged value is based on the ratio by diner because of the functional unit of this study. }\end{array}$} \\
\hline
\end{tabular}


Table 3.7

Dishwashing glass rack used during the full-scale experiment

\begin{tabular}{|c|c|c|c|}
\hline Days & ${ }^{1}$ Trays dining & Trayless dining & $\begin{array}{l}{ }^{2} \text { Percentage change based on the } \\
\text { ratio by diner }(\%)\end{array}$ \\
\hline Tuesday & 33 & 35 & 6.1 \\
\hline Wednesday & 42 & 32 & -23.8 \\
\hline Thursday & 33 & 35 & 6.1 \\
\hline Friday & 31 & 26 & -16.1 \\
\hline Saturday & 37 & 31 & -16.2 \\
\hline${ }^{3}$ Sunday & 36 & 32 & -11.1 \\
\hline Average value & 35.33 & \begin{tabular}{|l|}
31.8 \\
\end{tabular} & -10.0 \\
\hline \multicolumn{4}{|c|}{$\begin{array}{l}\text { Notes: } \\
{ }^{1} \text { Overall number of glass racks. } \\
{ }^{2} \text { Percentage change is calculated by (Ratio by diner trays dining - Ratio by diner trayless dining)/(Ratio by diner } \\
\text { trays dining) } * 100 \\
{ }^{3} \text { Sunday is excluded from the overall percentage change analysis because of the ice cream social. The ice cream } \\
\text { social was held at the conclusion of the experiment to thank the students for their cooperation. }\end{array}$} \\
\hline
\end{tabular}

Data in Table 3.6 and Table 3.7 indicate that the number of plates and glasses used by diners typically decreases when switching from dining with trays to dining without trays. During dining with trays, it was common for a student to have more than one dinner plate with food or glasses on their tray. With trayless dining, the students are still on average using more than one dinner plate per diner, but overall, there is a significant decrease in the number of plates and glasses used. The main reason for this decrease is that, without trays, diners were only taking one plate with food.

\subsubsection{Food Waste from Pre-rinse and Pan Washing Area}

Table 3.8 and Table 3.9 show the food waste from the pre-rinse and pan washing area for the full-scale experiment. The food waste from pans is the food scraped out of the empty or partially empty pans by the food service workers. Food waste from the prerinse area is the uneaten food that students returned to the dishwashing area. The total value and the ratio by diner are tabulated. Also included is the percent change in consumption based on the ratio by diner when converting from tray to trayless dining. 
Table 3.8

Food waste from the pre-rinse area for the full-scale experiment

\begin{tabular}{|c|c|c|c|c|c|}
\hline \multicolumn{6}{|c|}{ Food waste from pre- rinse area } \\
\hline & \multicolumn{2}{|c|}{ Trays dining } & \multicolumn{2}{|c|}{ Trayless dining } & \multirow[b]{2}{*}{$\begin{array}{c}{ }^{1} \text { Percent change } \\
\text { based on the } \\
\text { ratio by diner } \\
(\%)\end{array}$} \\
\hline Days & $\begin{array}{l}\text { Total } \\
\text { amount } \\
\text { (lbs) }\end{array}$ & $\begin{array}{l}\text { Ratio by } \\
\text { diner } \\
\text { (lbs/diner) }\end{array}$ & $\begin{array}{l}\text { Total } \\
\text { amount } \\
\text { (lbs) }\end{array}$ & $\begin{array}{l}\text { Ratio by } \\
\text { diner } \\
\text { (lbs/diner) }\end{array}$ & \\
\hline Tuesday & 120 & 0.168 & 115 & 0.162 & -3.6 \\
\hline Wednesday & 150 & 0.190 & 142 & 0.188 & -1.1 \\
\hline Thursday & 115 & 0.164 & 79 & 0.109 & -33.5 \\
\hline Friday & 156 & 0.242 & 93 & 0.162 & -33.1 \\
\hline Saturday & 152 & 0.227 & 82 & 0.124 & -45.4 \\
\hline${ }^{2}$ Sunday & 165 & 0.196 & 155 & 0.188 & -4.1 \\
\hline Total value & 693 & 0.991 & 511 & 0.745 & -24.8 \\
\hline $\begin{array}{l}{ }^{3} \text { Average } \\
\text { value }\end{array}$ & & 0.198 & & 0.149 & -24.7 \\
\hline \multicolumn{6}{|c|}{$\begin{array}{l}\text { Notes: } \\
{ }^{1} \text { Percentage change is calculated by (Ratio by diner trays dining - Ratio by diner trayless dining)/(Ratio by diner } \\
\text { trays dining) } * 100 \\
{ }^{2} \text { Sunday is excluded from the overall percentage change analysis because of the ice cream social. The ice cream } \\
\text { social was held at the conclusion of the experiment to thank the students for their cooperation. } \\
{ }^{3} \text { The average value is based on the ratio by diner because of the functional unit of this study. }\end{array}$} \\
\hline
\end{tabular}


Table 3.9

Food waste from the pan washing area for the full-scale experiment

\begin{tabular}{|c|c|c|c|c|c|}
\hline \multicolumn{6}{|c|}{ Food waste from pan washing area } \\
\hline & \multicolumn{2}{|c|}{ Trays dining } & \multicolumn{2}{|c|}{ Trayless dining } & \multirow[b]{2}{*}{$\begin{array}{c}{ }^{1} \text { Percent change } \\
\text { based on the } \\
\text { ratio by diner } \\
(\%)\end{array}$} \\
\hline Days & $\begin{array}{l}\text { Total } \\
\text { amount } \\
\text { (lbs) }\end{array}$ & $\begin{array}{l}\text { Ratio by } \\
\text { diner } \\
\text { (lbs/diner) }\end{array}$ & $\begin{array}{l}\text { Total } \\
\text { amount } \\
\text { (lbs) }\end{array}$ & $\begin{array}{l}\text { Ratio by } \\
\text { diner } \\
\text { (lbs/diner) }\end{array}$ & \\
\hline Tuesday & 34 & 0.048 & 29 & 0.041 & -14.6 \\
\hline Wednesday & 57 & 0.072 & 20 & 0.026 & -63.9 \\
\hline Thursday & 28 & 0.040 & 24 & 0.033 & -17.5 \\
\hline Friday & 35 & 0.054 & 28 & 0.049 & -9.3 \\
\hline Saturday & 47 & 0.070 & 16 & 0.024 & -65.7 \\
\hline${ }^{2}$ Sunday & 37 & 0.044 & 30 & 0.036 & -18.2 \\
\hline Total value & 201 & 0.284 & 117 & 0.173 & -39.1 \\
\hline $\begin{array}{l}{ }^{3} \text { Average } \\
\text { value }\end{array}$ & & 0.057 & & 0.035 & -38.6 \\
\hline \multicolumn{6}{|c|}{$\begin{array}{l}\text { Notes: } \\
{ }^{1} \text { Percentage change is calculated by (Ratio by diner trays dining - Ratio by diner trayless dining)/(Ratio by diner } \\
\text { trays dining) } * 100 \\
{ }^{2} \text { Sunday is excluded from the overall percentage change analysis because of the ice cream social. The ice cream } \\
\text { social was held at the conclusion of the experiment to thank the students for their cooperation. } \\
{ }^{3} \text { The average value is based on the ratio by diner because of the functional unit of this study. }\end{array}$} \\
\hline
\end{tabular}

The study shows that trayless dining reduces food waste because diners are carrying less food. When dining with trays, students frequently take more food than they consume. Without trays, diners will take smaller amounts of food and consume most of what they do take. Another note to mention is the decreases in food waste from pan washing area because the average unserved food (See Table 3.11) decreased in the trayless dining experiment; diners consumed more food in the trayless dining experiment.

For each day of the test, there is a reduction of food waste when not using trays. Saturday yielded the greatest difference, with a savings of 0.103 pounds per diner from the pre-rinse area, which is a $45.4 \%$ reduction in food waste, and 0.046 pounds per diner from the pan washing area, which is a $65.7 \%$ reduction in food waste. The total savings for the dinner shifts only when not using trays for the standard academic year (205 days) with an average number of 700 diners would be 7,032 pounds of food waste from the prerinse area and 3,157 pounds of food waste from the pan washing area. 


\subsubsection{Food Prepared, Unserved, and Consumed}

Dining Services provided data on the amount of prepared and unserved (prepared but unserved) food, and using these values, the amount served was calculated. Table 3.10, Table 3.11, and

Table 3.12 shows the prepared, unserved, and consumed food for the full-scale experiment. The total value and the ratio by diner are tabulated. Also included is the percent in change of consumption based on the ratio by diner when converting from tray to trayless dining.

Table 3.10

Prepared food for the full-scale experiment

\begin{tabular}{|c|c|c|c|c|}
\hline \multicolumn{5}{|c|}{ Prepared food } \\
\hline & \multicolumn{2}{|c|}{ Trays dining } & \multicolumn{2}{|c|}{ Trayless dining } \\
\hline Days & $\begin{array}{c}\text { Total } \\
\text { amount } \\
\text { (lbs) }\end{array}$ & $\begin{array}{l}\text { Ratio by } \\
\text { diner } \\
\text { (lbs/diner) }\end{array}$ & $\begin{array}{c}\text { Total } \\
\text { amount } \\
\text { (lbs) }\end{array}$ & $\begin{array}{l}\text { Ratio by } \\
\text { diner } \\
\text { (lbs/diner) }\end{array}$ \\
\hline${ }^{1}$ Tuesday & 345 & 0.48 & 350 & 0.49 \\
\hline Wednesday & 715 & 0.91 & 700 & 0.93 \\
\hline Thursday & 600 & 0.86 & 605 & 0.83 \\
\hline Friday & 330 & 0.51 & 330 & 0.57 \\
\hline Saturday & 507 & 0.76 & 473 & 0.71 \\
\hline${ }^{2}$ Sunday & 584 & 0.70 & 623.8 & 0.76 \\
\hline${ }^{3}$ Average value & & 0.70 & & 0.71 \\
\hline \multicolumn{5}{|c|}{$\begin{array}{l}\text { Notes: } \\
{ }^{1} \text { Main dishes are: } \\
\text { - Tuesday: Swedish meatballs, panko chicken, cut green beans, egg noodles, pesto sauce } \\
\text { - Wednesday: Chicken strips, lasagna, seasoned redskins, corn, garlic bread } \\
\text { - Thursday: Teriyaki chicken dippers, tacos, curly fries, broccoli } \\
\text { - } \quad \text { Friday: Buffalo chicken wings, fish, egg-roles, peas, tater tots } \\
\text { - Saturday: Chicken fries, shrimp basket, mush Swiss burger, vegetable baked beans, pasta, } \\
\text { chicken dippers } \\
{ }^{2} \text { Sunday is excluded from the overall percentage change analysis because of the ice cream } \\
\text { social. The ice cream social was held at the conclusion of the experiment to thank the students } \\
\text { for their cooperation. } \\
{ }^{3} \text { The average value is based on the ratio by diner because of the functional unit of this study. }\end{array}$} \\
\hline
\end{tabular}


Table 3.11

Unserved food for the full-scale experiment

\begin{tabular}{|c|c|c|c|c|}
\hline \multicolumn{5}{|c|}{ Unserved food } \\
\hline & \multicolumn{2}{|c|}{ Trays dining } & \multicolumn{2}{|c|}{ Trayless dining } \\
\hline Days & $\begin{array}{l}\text { Total } \\
\text { amount } \\
\text { (lbs) }\end{array}$ & $\begin{array}{l}\text { Ratio by } \\
\text { diner } \\
\text { (lbs/diner) }\end{array}$ & $\begin{array}{l}\text { Total } \\
\text { amount } \\
\text { (lbs) }\end{array}$ & $\begin{array}{l}\text { Ratio by } \\
\text { diner } \\
\text { (lbs/diner) }\end{array}$ \\
\hline Tuesday & 10.5 & 0.015 & 25 & 0.035 \\
\hline Wednesday & 28.8 & 0.037 & 42.57 & 0.056 \\
\hline Thursday & 93.6 & 0.134 & 38.10 & 0.053 \\
\hline Friday & 3.3 & 0.005 & 7.7 & 0.013 \\
\hline Saturday & 7 & 0.01 & 13.5 & 0.020 \\
\hline${ }^{1}$ Sunday & 128 & 0.152 & 17.7 & 0.021 \\
\hline${ }^{2}$ Average value & & 0.042 & & 0.035 \\
\hline \multicolumn{5}{|c|}{$\begin{array}{l}\text { Notes: } \\
{ }^{1} \text { Sunday is excluded from the overall percentage change analysis because of the ice cream social. } \\
\text { The ice cream social was held at the conclusion of the experiment to thank the students for their } \\
\text { cooperation. } \\
{ }^{2} \text { The averaged value is based on the ratio by diner because of the functional unit of this study. }\end{array}$} \\
\hline
\end{tabular}

Table 3.12

Food consumed results for full-scale experiment

\begin{tabular}{|c|c|c|c|c|c|}
\hline & \multicolumn{5}{|c|}{${ }^{4}$ Consumed food } \\
\hline & \multicolumn{2}{|c|}{ Trays dining } & \multicolumn{2}{|c|}{ Trayless dining } & \multirow[b]{2}{*}{$\begin{array}{c}{ }^{1} \text { Percent } \\
\text { change based } \\
\text { on the ratio by } \\
\text { diner }(\%)\end{array}$} \\
\hline Days & $\begin{array}{c}\text { Total } \\
\text { amount } \\
\text { (lbs) }\end{array}$ & $\begin{array}{l}\text { Ratio by } \\
\text { diner } \\
\text { (lbs/diner) }\end{array}$ & $\begin{array}{c}\text { Total } \\
\text { amount } \\
\text { (lbs) }\end{array}$ & $\begin{array}{l}\text { Ratio by } \\
\text { diner } \\
\text { (lbs/diner) }\end{array}$ & \\
\hline Tuesday & 180.5 & 0.253 & 181 & 0.256 & 1.2 \\
\hline Wednesday & 479.2 & 0.608 & 495.4 & 0.655 & 7.7 \\
\hline Thursday & 363.4 & 0.519 & 463.9 & 0.640 & 23.3 \\
\hline Friday & 135.7 & 0.210 & 201.3 & 0.351 & 67.1 \\
\hline Saturday & 301 & 0.449 & 361.5 & 0.545 & 21.4 \\
\hline${ }^{2}$ Sunday & 254 & 0.302 & 421.1 & 0.510 & 68.9 \\
\hline Total value & 1459.8 & 2.04 & 1703.1 & 2.45 & 20.1 \\
\hline${ }^{3}$ Average value & & 0.407 & & 0.489 & 20.2 \\
\hline \multicolumn{6}{|c|}{$\begin{array}{l}\text { Notes: } \\
\text { Percentage change is calculated by (Ratio by diner trays dining - Ratio by diner trayless dining)/(Ratio by diner } \\
\text { trays dining) } * 100 \\
{ }^{2} \text { Sunday is excluded from the overall percentage change analysis because of the ice cream social. The ice cream } \\
\text { social was held at the conclusion of the experiment to thank the students for their cooperation. } \\
{ }^{3} \text { The average value is based on the ratio by diner because of the functional unit of this study. } \\
{ }^{4} \text { Consumed food = prepared food - unserved food - food waste from pre-rinse area - food waste from pan washing } \\
\text { area. }\end{array}$} \\
\hline
\end{tabular}


Data from Table 3.13 indicates that for each day of the study the diners consumed more food during the trayless portion of the experiment. Further study would be required to identify the reason for the increased consumption, but it could be that the diners found it more convenient to eat the extra food on their plate instead of carrying it back for disposal. It would be interesting to determine if the increased consumption would continue after the students became acclimated to trayless dining.

The significant variations in the weight of consumed food for some of the days of the study are due, in part, to the popularity of the main dish and to the inedible components of the food - for example, chicken bones. As previously stated in the methods section, this study only accounted for main dish items. On days when the main dish served was less popular, students would eat more of the side dishes, such as the salad bar, french fries, hamburgers, and the self-cooking area.

\subsubsection{Dishwashing Machine Water Consumption}

Table 3.13 shows the dishwashing machine water consumption for the full-scale experiment. The total value and the ratio by diner were tabulated. Also included is the percent change in water consumption based on the ratio by diner when converting from tray to trayless dining. 
Table 3.13

Dishwasher machine water consumption for the full-scale experiment

\begin{tabular}{|c|c|c|c|c|c|}
\hline \multicolumn{6}{|c|}{${ }^{4}$ Dishwasher machine water consumption } \\
\hline & \multicolumn{2}{|c|}{ Trays dining } & \multicolumn{2}{|c|}{ Trayless dining } & \multirow[b]{2}{*}{$\begin{array}{c}{ }^{1} \text { Percent change } \\
\text { in based on the } \\
\text { ratio by diner } \\
(\%)\end{array}$} \\
\hline Days & $\begin{array}{l}\text { Total } \\
\text { amount } \\
\text { (gal) }\end{array}$ & $\begin{array}{l}\text { Ratio by } \\
\text { diner } \\
\text { (gal/diner) }\end{array}$ & $\begin{array}{l}\text { Total } \\
\text { amount } \\
\text { (gal) }\end{array}$ & $\begin{array}{l}\text { Ratio by } \\
\text { diner } \\
\text { (gal/diner) }\end{array}$ & \\
\hline Tuesday & 147 & 0.21 & 130 & 0.18 & -14.3 \\
\hline Wednesday & 202.5 & 0.26 & 166 & 0.22 & -15.4 \\
\hline Thursday & 225 & 0.32 & 169 & 0.23 & -28.1 \\
\hline Friday & 205 & 0.29 & 175 & 0.32 & 10.3 \\
\hline Saturday & 223 & 0.33 & 215 & 0.32 & -3.0 \\
\hline${ }^{2}$ Sunday & 296 & 0.35 & 310 & 0.37 & -5.7 \\
\hline Total value & 1002.5 & 1.41 & 855 & 1.27 & -9.9 \\
\hline $\begin{array}{l}{ }^{3} \text { Average } \\
\text { value }\end{array}$ & & 0.28 & & 0.25 & -9.9 \\
\hline \multicolumn{6}{|c|}{$\begin{array}{l}\text { Notes: } \\
{ }^{1} \text { Percentage change is calculated by (Ratio by diner trays dining - Ratio by diner trayless dining)/(Ratio by diner } \\
\text { trays dining) *100 } \\
{ }^{2} \text { Sunday is excluded from the overall percentage change analysis because of the ice cream social. The ice cream } \\
\text { social was held at the conclusion of the experiment to thank the students for their cooperation } \\
{ }^{3} \text { The average value is based on the ratio by diner because of the functional unit of this study. } \\
{ }^{4} \text { Raw data is provided in Appendix B. }\end{array}$} \\
\hline
\end{tabular}

Table 3.13 shows a decrease in dishwasher water consumption when converting to trayless dining for each day of the study. This decrease parallels the reduction in dishwasher electrical consumption. The average reduction of dishwasher consumption over the duration of the study was $9.9 \%$. If trayless dining were implemented, this would result in a decrease of 4,305 gallons of consumption and wastewater discharge for the dinner shift over the academic year, based on 205 days of operation per year with an average of 700 diners.

\subsubsection{Steam}

Table 3.14 shows the steam consumption for the full-scale experiment. The total value and the ratio by diner are tabulated. Also included is the percent change in steam consumption based on the ratio by diner when converting from tray to trayless dining. 
Table 3.14

Steam consumption in the full-scale experiment

\begin{tabular}{|c|c|c|c|c|c|}
\hline \multicolumn{6}{|c|}{ Steam consumption } \\
\hline & \multicolumn{2}{|c|}{ Trays dining } & \multicolumn{2}{|c|}{ Trayless dining } & \multirow[b]{2}{*}{$\begin{array}{l}{ }^{2} \text { Percent } \\
\text { change } \\
\text { based on the } \\
\text { ratio by } \\
\text { diner }(\%)\end{array}$} \\
\hline Days & $\begin{array}{c}{ }^{1} \text { Total } \\
\text { amount } \\
\text { (mmBTU) }\end{array}$ & $\begin{array}{c}\text { Ratio by } \\
\text { diner } \\
\text { (mmBTU) }\end{array}$ & $\begin{array}{c}\text { Total } \\
\text { amount } \\
\text { (mmBTU) }\end{array}$ & $\begin{array}{l}\text { Ratio by } \\
\text { diner } \\
\text { (mmBTU) }\end{array}$ & \\
\hline Tuesday & 0.11 & 0.00016 & 0.01 & 0.00013 & -15.2 \\
\hline Wednesday & 0.15 & 0.00019 & 0.12 & 0.00016 & -16.3 \\
\hline Thursday & 0.17 & 0.00024 & 0.13 & 0.00017 & -28.9 \\
\hline Friday & 0.15 & 0.00022 & 0.13 & 0.00023 & 9.2 \\
\hline Saturday & 0.17 & 0.00024 & 0.16 & 0.00023 & -4.1 \\
\hline${ }^{3}$ Sunday & 0.22 & 0.00026 & 0.23 & 0.00027 & 4.6 \\
\hline Total value & 0.75 & 0.00105 & 0.55 & 0.00092 & -10.9 \\
\hline${ }^{4}$ Average value & & 0.00021 & & 0.00018 & -10.9 \\
\hline \multicolumn{6}{|c|}{$\begin{array}{l}\text { Notes: } \\
{ }^{1} \text { mmBTU stands for one million BTUs. } \\
{ }^{2} \text { Percentage change is calculated by (Ratio by diner trays dining - Ratio by diner trayless dining)/(Ratio by diner } \\
\text { trays dining) *100 } \\
{ }^{3} \text { Sunday is excluded from the because of the ice cream social. The ice cream social was held at the conclusion of } \\
\text { the experiment to thank the students for their cooperation. } \\
{ }^{4} \text { The average value is based on the ratio by diner because of the functional unit of this study. }\end{array}$} \\
\hline
\end{tabular}

Table 3.14 shows a decrease in steam consumption when converting to trayless dining for each day of the study, except for Sunday, which was not included in the analysis because of the unplanned ice cream social. Steam use decreases because of the reduced water consumption for the dishwashing machine. The average reduction of steam consumption over the duration of the study was $10.9 \%$.

Based on the average results, the total savings when not using trays for the standard 205-day academic year with an average of 700 diners would be $2.87 \mathrm{mmBTU}$ for the dinner shift.

\subsubsection{Electrical Data}

Table 3.15 shows the electrical consumption for the dishwasher during the fullscale experiment. Both the total value and the ratio by diner are shown. Also included is the percentage change in electrical consumption based on the ratio by diner when converting from tray to trayless dining. 
Table 3.15

Dishwasher electrical consumption data for the full scale experiment

\begin{tabular}{|c|c|c|c|c|c|}
\hline & \multicolumn{5}{|c|}{${ }^{4}$ Electrical consumption } \\
\hline & \multicolumn{2}{|c|}{ Trays dining } & \multicolumn{2}{|c|}{ Trayless dining } & \\
\hline Days & $\begin{array}{l}\text { Total } \\
\text { value } \\
(\mathrm{kWh})\end{array}$ & $\begin{array}{c}\text { Ratio by } \\
\text { diner } \\
\text { (kWh/diner) }\end{array}$ & $\begin{array}{l}\text { Total } \\
\text { value } \\
(\mathrm{kWh})\end{array}$ & $\begin{array}{c}\text { Ratio by } \\
\text { diner } \\
\text { (kWh/diner) }\end{array}$ & $\begin{array}{c}{ }^{1} \text { Percentage } \\
\text { change based on } \\
\text { the ratio by diner } \\
(\%)\end{array}$ \\
\hline Tuesday & 10.9 & 0.0153 & 10 & 0.0141 & -7.8 \\
\hline Wednesday & 12 & 0.0152 & 11.2 & 0.0148 & -2.6 \\
\hline Thursday & 11.8 & 0.0169 & 10.6 & 0.0146 & -13.6 \\
\hline Friday & 12 & 0.0186 & 9.9 & 0.0172 & -7.5 \\
\hline Saturday & 13.2 & 0.0197 & 12.8 & 0.0193 & -2.0 \\
\hline${ }^{2}$ Sunday & 13.8 & 0.0164 & 9.9 & 0.0120 & -26.8 \\
\hline $\begin{array}{l}\text { Total } \\
\text { Value }\end{array}$ & 59.9 & 0.0857 & 54.5 & 0.0800 & -6.7 \\
\hline $\begin{array}{l}{ }^{3} \text { Average } \\
\text { value }\end{array}$ & & 0.0171 & & 0.0160 & -6.4 \\
\hline \multicolumn{6}{|c|}{$\begin{array}{l}\text { Notes: } \\
{ }^{1} \text { Percentage change is calculated by (Ratio by diner trays dining - Ratio by diner trayless dining)/(Ratio by diner } \\
\text { trays dining) *100 } \\
{ }^{2} \text { Sunday is excluded from the overall percentage change analysis because of the ice cream social. The ice cream } \\
\text { social was held at the conclusion of the experiment to thank the students for their cooperation. } \\
{ }^{3} \text { The average value is based on the ratio by diner because of the functional unit of this study. } \\
{ }^{4} \text { Raw data is provided in Appendix B. }\end{array}$} \\
\hline
\end{tabular}

Table 3.15 shows a reduction in dishwasher electrical consumption for each day

of the study when converting to trayless dining. The primary reason for the change is the reduction in tableware to be washed: trays, plates, glassware, etc. The overall percentage reduction for the study was $6.4 \%$. If trayless dining were implemented, this would result in a decrease of $158 \mathrm{kWh}$ for the dinner shift over the academic year based on 205 days of operation per year with an average of 700 diners.

\subsection{Life Cycle Cost Analysis}

This study accounted for purchasing cost along with usage cost. Mr. Hiltunen, the director of Michigan Tech Dining Services, provided the purchasing cost of the trays used in Wadsworth Hall. The electricity, water, and steam costs are based on current local bills at Michigan Technological University, which were obtained from Mr. David 
Taivalkoski, Energy Manager at Michigan Tech. Table 3.16 shows the life cycle cost of the full-scale experiment.

Table 3.16

Life cycle cost analysis

\begin{tabular}{|c|c|c|c|c|}
\hline & Price/ unit & Cost (\$/unit) & $\begin{array}{c}{ }^{1} \text { Trayless dining } \\
\text { (\$/205 days) }\end{array}$ & $\begin{array}{l}{ }^{2} \text { Trays dining } \\
\text { (\$/205 days) }\end{array}$ \\
\hline \multicolumn{5}{|l|}{$\begin{array}{c}\text { Purchasing } \\
\text { cost }\end{array}$} \\
\hline $\begin{array}{c}\text { Purchasing } \\
\text { trays }\end{array}$ & $\$ /$ tray & 1.37 & $\mathrm{X}$ & 93.51 \\
\hline \multicolumn{5}{|l|}{ Usage cost } \\
\hline${ }^{3}$ Water & \$/gallon & 0.01109 & 397.85 & 445.59 \\
\hline Electricity & $\$ / \mathrm{kWh}$ & 0.08 & 183.68 & 196.30 \\
\hline Steam & $\$ / \mathrm{mmBTU}$ & 12.75 & 347.62 & 384.22 \\
\hline Overall cost & dollars & & 929.15 & 1119.62 \\
\hline${ }^{4}$ Total saving & \multicolumn{4}{|c|}{$\$ 190.4$} \\
\hline \multicolumn{5}{|c|}{ 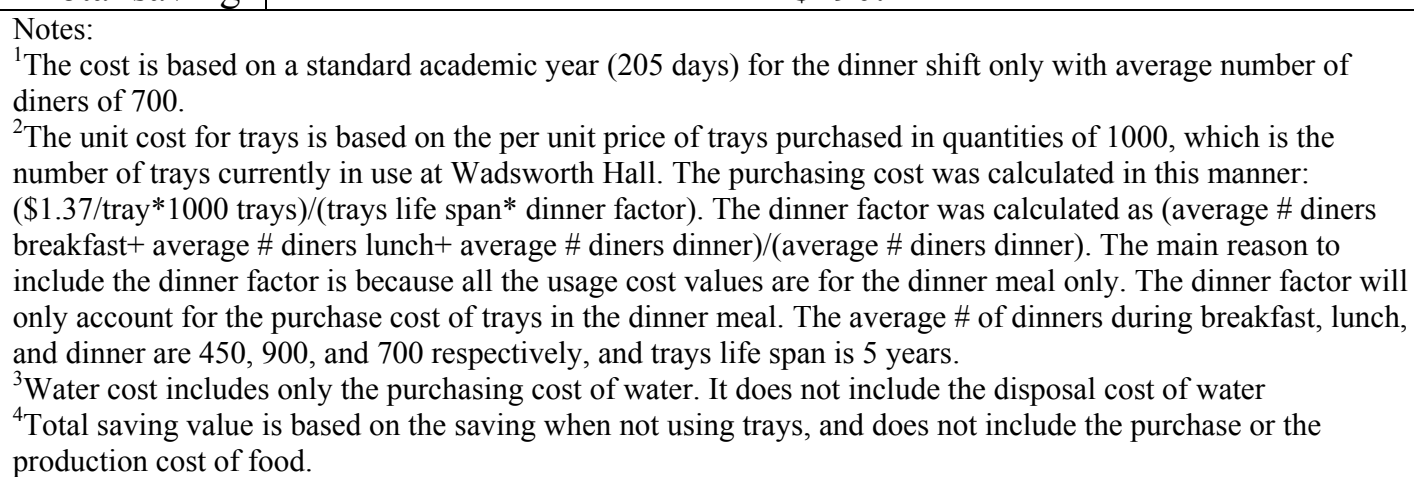 } \\
\hline
\end{tabular}

Table 3.16 indicates that trayless dining reduces costs for all items measured. There is a total savings of $\$ 190.4$ when not using trays during the dinner shift for the standard academic year, 205 days, assuming an average number of diners of 700 . There will be a similar savings for any facility that has features (e.g., using a similar dishwasher machine, similar number of diners) similar to Michigan Technological University dining, if the facility transitions to trayless dining.

\subsection{Environmental Impact Analysis}

Table 3.17 and Table 3.18 address the total greenhouse gas emissions a unit of $\mathrm{kg}$ $\mathrm{CO}_{2}$ equivalent (eq) by using the IPCC 2007 GWP 100a method and the Cumulative Energy Demand (CED) for the manufacturing of the trays, usage phase of the full-scale experiment, and end of life cycle. The usage phase includes dishwashing machine water, 
steam, and electrical consumption from Table 3.13, Table 3.14, and Table 3.15. The end of life cycle includes wastewater and food waste from pre-rinse and pan washing area. The data are based on the functional unit of one dinner meal.

Table 3.17

Environmental impact analysis by using the IPCC 2007 GWP 100a method

\begin{tabular}{|c|c|c|c|c|c|c|}
\hline & \multicolumn{3}{|c|}{ Trays dining $\left(\mathrm{kg} \mathrm{CO}_{2} \mathrm{eq}\right)$} & \multicolumn{3}{|c|}{ Trayless dining $\left(\mathrm{kg} \mathrm{CO}_{2} \mathrm{eq}\right)$} \\
\hline & ${ }^{3}$ Manufacturing & ${ }^{1}$ Usage & $\begin{array}{c}{ }^{2} \text { End } \\
\text { life } \\
\text { cycle }\end{array}$ & Manufacturing & $\begin{array}{l}\text { Usage } \\
\text { phase }\end{array}$ & $\begin{array}{l}\text { End } \\
\text { life } \\
\text { cycle }\end{array}$ \\
\hline Tuesday & 5.32 & 0.048 & 0.14 & 0 & 0.043 & 0.13 \\
\hline Wednesday & 5.79 & 0.055 & 0.17 & 0 & 0.049 & 0.14 \\
\hline Thursday & 5.51 & 0.066 & 0.13 & 0 & 0.051 & 0.09 \\
\hline Friday & 5.47 & 0.068 & 0.19 & 0 & 0.064 & 0.14 \\
\hline Saturday & 5.54 & 0.071 & 0.19 & 0 & 0.069 & 0.10 \\
\hline Average & 5.53 & 0.062 & 0.16 & 0 & 0.055 & 0.12 \\
\hline $\begin{array}{l}700 \text { Average } \\
\text { diners }\end{array}$ & 3871 & 43.4 & 115.5 & 0 & 38.5 & 84.0 \\
\hline $\begin{array}{c}\text { Standard } \\
\text { academic } \\
\text { year (205 } \\
\text { days) }\end{array}$ & 363.1 & 8897 & 23677.5 & 0 & 7892.5 & 17220 \\
\hline $\begin{array}{c}\text { Difference } \\
\left(\mathrm{kg} \mathrm{CO}_{2} \mathrm{eq}\right)\end{array}$ & \multicolumn{6}{|c|}{7825} \\
\hline \multicolumn{7}{|c|}{$\begin{array}{l}\text { Notes: } \\
{ }^{1} \text { The usage values are based on the ratio by diner because of the functional unit of this study and includes } \\
\text { dishwashing machine water, steam, and electrical consumption from tables } 3.13,3.14 \text {, and } 3.15 \text {. } \\
{ }^{2} \text { The end of life cycle values are based on the ratio by diner because of the functional unit of this study. } \\
{ }^{3} \text { The average value under the manufacturing phase multiplied by the average number of diners. The manufacturing } \\
\text { impact of trays in column (Standard academic year } 205 \text { days) was calculated by this manner: } \\
\text { (Environmental impact to produce one tray* existing number of trays at Wadsworth Hall)/(life span of } \\
\text { trays*dinner factor). } \\
\text { Environmental impact to produce one tray is } 5.32 \mathrm{~kg} \mathrm{CO}_{2} \text { eq } \\
\text { Existing number of trays is } 1000 \\
\text { Life span of trays is } 5 \text { years } \\
\text { The dinner factor was calculated as (average \# diners breakfast }+ \text { average \# diners lunch }+ \text { average \# diners } \\
\text { dinner)/(average \# diners dinner). The main reason to include the dinner factor is because all the usage cost values } \\
\text { are for the dinner meal only. The dinner factor will only account for the purchase cost of trays in the dinner meal. } \\
\text { The average \# of dinners during breakfast, lunch, and dinner are } 450,900 \text {, and } 700 \text { respectively. }\end{array}$} \\
\hline
\end{tabular}


Table 3.18

Environmental impact analysis by using the cumulative energy demand method

\begin{tabular}{|c|c|c|c|c|c|c|}
\hline & \multicolumn{3}{|c|}{ Trays dining (MJ eq) } & \multicolumn{3}{|c|}{ Trayless Dining (MJ eq) } \\
\hline & ${ }^{3}$ Manufacturing & ${ }^{1}$ Usage & $\begin{array}{l}{ }^{2} \text { End } \\
\text { life } \\
\text { cycle }\end{array}$ & Manufacturing & $\begin{array}{l}\text { Usage } \\
\text { phase }\end{array}$ & $\begin{array}{l}\text { End } \\
\text { life } \\
\text { cycle }\end{array}$ \\
\hline Tuesday & 5.32 & 0.048 & 0.042 & 0 & 0.044 & 0.039 \\
\hline Wednesday & 5.79 & 0.055 & 0.051 & 0 & 0.050 & 0.042 \\
\hline Thursday & 5.51 & 0.066 & 0.042 & 0 & 0.051 & 0.029 \\
\hline Friday & 5.47 & 0.068 & 0.058 & 0 & 0.064 & 0.043 \\
\hline Saturday & 5.54 & 0.071 & 0.059 & 0 & 0.070 & 0.032 \\
\hline Average & 5.53 & 0.062 & 0.050 & 0 & 0.056 & 0.037 \\
\hline $\begin{array}{c}700 \\
\text { Average } \\
\text { diners }\end{array}$ & 3871 & 43.4 & 35.0 & 0 & 39.2 & 26.1 \\
\hline $\begin{array}{c}\text { Standard } \\
\text { academic } \\
\text { year }(205 \\
\text { days })\end{array}$ & 363.1 & 8897 & 7175.0 & 0 & 8036 & 5354.5 \\
\hline $\begin{array}{c}\text { Difference } \\
(\mathrm{MJ} \text { eq) }\end{array}$ & \multicolumn{6}{|c|}{3045} \\
\hline \multicolumn{7}{|c|}{$\begin{array}{l}\text { Notes: } \\
{ }^{1} \text { The usage values are based on the ratio by diner because of the functional unit of this study and include } \\
\text { dishwashing machine water, steam, and electrical consumption from tables } 3.13,3.14 \text {, and } 3.15 \text {. } \\
{ }^{2} \text { The end of life cycle values are based on the ratio by diner because of the functional unit of this study. } \\
\text { } \text { The average value under the manufacturing phase multiplied by the average number of diners. The manufacturing } \\
\text { impact of trays in column (Standard academic year } 205 \text { days) was calculated by this manner: } \\
\text { (Environmental impact to produce one tray* existing number of trays at Wadsworth Hall)/(life span of } \\
\text { trays*dinner factor). } \\
\text { Environmental impact to produce one tray is } 5.32 \mathrm{MJ} \text { eq } \\
\text { Existing number of trays is } 1000 \\
\text { Life span of trays is } 5 \text { years } \\
\text { The dinner factor was calculated as (average \# diners breakfast }+ \text { average \# diners lunch }+ \text { average \# diners } \\
\text { dinner)/(average \# diners dinner). The main reason to include the dinner factor is because all the usage cost values } \\
\text { are for the dinner meal only. The dinner factor will only account for the purchase cost of trays in the dinner meal. } \\
\text { The average \# of dinners during breakfast, lunch, and dinner are } 450,900 \text {, and } 700 \text { respectively. }\end{array}$} \\
\hline
\end{tabular}

According to Table 3.17 and Table 3.18, there are more greenhouse emissions when dining with trays. Purchasing trays for one residential hall will result in extra purchasing costs and environmental impacts. Besides the extra green house emissions and cumulative energy demand in the tray dining usage phase, there is a manufacturing impact associated; creating one tray produces $5.32 \mathrm{~kg}$ of $\mathrm{CO}_{2}$ eq and $89.9 \mathrm{MJ}$ eq. The added environmental impact values can be removed when shifting to trayless dining. Trayless dining produces a zero amount of $\mathrm{CO}_{2}$ eq and cumulative energy demand in the 
manufacturing stage, reductions of $1005 \mathrm{~kg} \mathrm{CO}_{2}$ eq and $861 \mathrm{MJ}$ eq in the usage phase, reductions of $6458 \mathrm{~kg} \mathrm{CO}_{2}$ eq and $1821 \mathrm{MJ}$ eq in the end of the life cycle, and overall reductions of $8830 \mathrm{CO}_{2}$ eq and $3906 \mathrm{MJ}$ eq. Green dining facilities should consider these applications because they carry fewer environmental impacts. 


\section{Conclusion}

The results of this study indicate that trayless dining can reduce water, electricity, and steam consumption, can generate potential cost savings, and can reduce environmental impacts. The study shows that trayless dining reduces food expenditures because diners are wasting less food. The total savings when not using trays for the dinner shift for the standard academic year (205 days) with an average number of 700 diners is 7,031.5 pounds of food waste from the pre-rinse area and 3,157 pounds of food waste from the pan washing area. Moreover, for each day of the study, the diners consumed more food during the trayless portion of the experiment. Further study would be required to identify the reason for the increased food consumption, but it could be that the diners found it more convenient to eat the extra food on their plate instead of carrying it back for disposal. It would be interesting to determine if the increased consumption would continue after the students became acclimated to the trayless dining system.

The trayless dining experiment shows a reduction in dishwasher water, steam, and electrical consumption for each day of the study. The average reductions in dishwasher water, steam, and electrical consumption over the duration of the study were $9.9 \%$, $10.9 \%$, and $6.4 \%$, respectively. If trayless dining were implemented, this would result in a decrease of 4,305 gallons of water consumption and wastewater discharge, 2.87 mmBTU of steam consumption, and $158 \mathrm{kWh}$ of electrical consumption for the dinner shift over the academic year, based on 205 days of operation with an average of 700 diners.

Based on the LCA, there is a total savings of $\$ 190.4$ when not using trays during the dinner shift for the 205-day standard academic year. There will be an extra savings for any new facility that has features (e.g., using a similar dishwasher machine, similar number of diners) similar to Michigan Technological University dining if the facility is not purchasing trays.

Trayless dining produces zero amount of $\mathrm{CO}_{2}$ eq and cumulative energy demand in the manufacturing stage for the trays, reductions of $1005 \mathrm{~kg} \mathrm{CO}_{2}$ eq and $861 \mathrm{MJ}$ eq in the usage phase, reductions of $6458 \mathrm{~kg} \mathrm{CO}_{2}$ eq and $1821 \mathrm{MJ}$ eq in the end of the life cycle, and overall reductions of $8830 \mathrm{CO}_{2}$ eq and $3906 \mathrm{MJ}$ eq. 
This study suggests implementation of trayless dining at the beginning of the academic year so that incoming freshmen are more accustomed to dining without trays. Furthermore, providing students with data on the advantages of going trayless will be helpful in the implementation process. 


\section{References}

Allen DT, Shonnard DR. 2002. Green engineering environmentally conscious design of chemical processes. Upper Saddle River: Prentice Hall PTR.

ARAMARK Higher Education. 2008. The Business and Cultural Acceptance Case for Trayless Dining

Bon Appétit Management Company Leads Food Service Industry In Reducing Greenhouse Gas Emissions from Food Waste [Internet]. 2009. [updated Nov 2009, cited Oct 2010]. Available from: http://www.bamco.com/newsroom/in-thenews/press-releases/post/40-food-waste-reductions

Cambro Manufacturing Company. 2011. Camtrays.

Carlisle FoodService Products. 2011. China Plate Material.

Confidence Interval for Means Calculator [Internet]. 2005. [updated Oct 2005, cited Dec 2010]. Available from:

http://www.dimensionresearch.com/resources/resources_overview.html

Hall W. 2011. Personal Conversation. Wojick C, editor. Houghton,MI 49931.

Hiltunen R. 2009. Trayless Dining at Michigan Tech University Meeting. Blaisi N, editor. Houghton,MI 49931.

Product Ecology Consultants. 2010. About SimaPro. http://www.pre-sustainability.com/content/simapro-lca-software/

American University Environmental Science Department Finds Cafeteria Waste Reduction in Trayless Study [Internet]. 2009. American University [updated April 2009, cited June 2010]. Available from:

http://academic3.american.edu/ hayesd7/AU_Food_Waste_Research_Press_Rele ase.htm

Taivalkoski D. 2010. Trayless Dining Meeting at Michigan Tech.In: Blaisi N, editor.Houghton,MI 49931.

Performing the interpretation in LCA [Internet]. 2011. [updated June 2011, cited July 2010]. Available from: http://www.tosca-life.info/life-cycle-assessment/how-toperform-an-lca/phases-in-an-lca-study/interpretation/

Software S.2010. SimaPro Software Description $7^{\text {th }}$ ed. 
Upcraft ML, Schuh JH. 1996. Assessment in student affairs:A guide for practitioners. Jossey-Bass.

UPPCO. 2011. Percentage of Fuel Type Used to Produce Electricity in Michigan, Illinois, Indiana, Ohio and Wisconsin. 


\section{Appendix A: Sample Calculation}

\section{First pilot test consumed food weight on Tuesday:}

Consumed food weight $=$ prepared food - unserved food - (food waste from pre-rinse area

+ food waste from pan washing area)

- Prepared food $=485 \mathrm{lbs}$

- Unserved food=40 lbs

- Food waste from pre-rinse area $=145.5 \mathrm{lbs}$

- Food waste from pan washing area $=46.5 \mathrm{lbs}$

Consumed food weight $=485 \mathrm{lbs}-40 \mathrm{lbs}-(145.5+46.5) \mathrm{lbs}$

Consumed food weight $=253 \mathrm{lbs}$

Second pilot test steam consumption on Tuesday:

$$
\text { Steam Consumption }=\text { Gallons of } \text { Water Consumed } * \frac{8.43 \mathrm{Ibs}}{\text { gallon }} * \frac{\left(\text { Temperature }_{\text {final }}-\text { Temperature }_{\text {Initial }}\right)}{1,000,000}
$$

- Dishwashing machine water consumption=272 gal

- Initial temperature dishwashing machine water $=68^{\circ} \mathrm{F}$

- Final temperature dishwashing machine water $=156^{\circ} \mathrm{F}$

Steam consumption $=272(\mathrm{gal}) * 8.43 \mathrm{lbs} / \mathrm{gal} *(156-68) / 1000000$

Steam consumption $=0.201 \mathrm{mmBTU}$

\section{Full-scale experiment consumed food weight on Tuesday February 152011 (Trays dining):}

Consumed food weight $=$ prepared food-unserved food $-($ food waste from pre-rinse area + food waste from pan washing area)

- $\quad$ Number of diners $=714$

- $\quad$ Prepared food $=345 \mathrm{lbs}$

- Unserved food $=10.5 \mathrm{lbs}$

- Food waste from pre-rinse area $=120 \mathrm{lbs}$

- Food waste from pan washing area=34 lbs

Consumed food weight $=345 \mathrm{lbs}-10.5 \mathrm{lbs}-(120+34) \mathrm{lbs}$

Consumed food weight $=180.5 \mathrm{lbs}$

Consumed food weight/diner $=180.5 / 714$

Consumed food $=0.253 \mathrm{lbs} /$ diner

Full scale experiment steam consumption on Tuesday February 152011 (Trays dining):

$$
\text { Steam Consumption }=\text { Gallons of } \text { Water Consumed } * \frac{8.43 \mathrm{Ibs}}{\text { gallon }} * \frac{\left(\text { Temperature }_{\text {final }}-\text { Temperature }_{\text {Initial }}\right)}{1,000,000}
$$

- Dishwashing machine water consumption=147 gal

- Initial temperature $=68^{\circ} \mathrm{F}$

- $\quad$ Final temperature $=156^{\circ} \mathrm{F}$

- $\quad$ Number of diners $=714$ 
Steam consumption $=147(\mathrm{gal}) * 8.43 \mathrm{lbs} / \mathrm{gal} *(156-68) / 1000000$

Steam consumption $=0.109 \mathrm{mmBTU}$

Steam consumption $=0.109 / 714$

Steam consumption $=0.000153 \mathrm{mmBTU}$ 


\section{Appendix B: Pilot and Full-Scale Experiment Raw Data}

Table B. 1

Second pilot test water consumption raw data

\begin{tabular}{|l|c|l|l|l|l|l|}
\hline & $\begin{array}{l}\text { Pre rinse } \\
\text { meter reading } \\
\text { at the start of } \\
\text { the shift (gal) }\end{array}$ & $\begin{array}{l}\text { Pre rinse meter } \\
\text { reading at the end } \\
\text { of the shift (gal) }\end{array}$ & $\begin{array}{l}\text { Pre rinse } \\
\text { water } \\
\text { consumption } \\
\text { (gal) }\end{array}$ & $\begin{array}{l}\text { Dishwasher } \\
\text { meter reading } \\
\text { at the start of } \\
\text { the shift (gal) }\end{array}$ & $\begin{array}{l}\text { Dishwasher } \\
\text { meter } \\
\text { reading at the } \\
\text { end of the } \\
\text { shift (gal) }\end{array}$ & $\begin{array}{l}\text { Dishwashing } \\
\text { machine } \\
\text { water } \\
\text { consumption } \\
\text { (gal) }\end{array}$ \\
\hline $\begin{array}{l}\text { Tue,07 Dec } \\
2010\end{array}$ & 5554.9 & 5567.5 & 12.6 & 131973 & 132245 & 272 \\
\hline Wed,08 Dec & 5596.2 & 5604.1 & 7.9 & 133185 & 133474 & 289 \\
\hline Thu,09 Dec & 5687.8 & 5705.8 & 18.0 & 134739 & 134955 & 216 \\
\hline Fri, 10 Dec & 5735.3 & 5743.3 & 8.0 & 135804 & 136045 & 241 \\
\hline Sat, 11 Dec & 5841.5 & 5828.4 & 13.1 & 136500 & 136751 & 251 \\
\hline Sun, 12 Dec & 5830.22 & 5854.4 & 24.18 & 137346 & 137703 & 357 \\
\hline Mon, 13 Dec & 5942.8 & 5979.3 & 36.5 & 139051.4 & 139348 & 296.6 \\
\hline
\end{tabular}


Table B.2

Second pilot test electrical consumption raw data

\begin{tabular}{|l|c|c|c|c|}
\hline Days & $\begin{array}{l}\text { Dishwasher } \\
\text { electricity meter } \\
\text { reading at the } \\
\text { start of the shift } \\
(\mathrm{kWh})\end{array}$ & $\begin{array}{l}\text { Dishwasher electricity } \\
\text { meter reading at the } \\
\text { end of the shift }(\mathrm{kWh})\end{array}$ & $\begin{array}{l}\text { Electricity } \\
\text { consumption for } \\
\text { the dishwasher } \\
(\mathrm{kWh})\end{array}$ & Diners \\
\hline Tue,07 Dec 2010 & 3595.5 & 3607.9 & 12.4 & 858 \\
\hline Wed,08 & 3632.5 & 3644.2 & 11.7 & 893 \\
\hline Thu,09 & 3666.2 & 3676.5 & 10.3 & 818 \\
\hline Fri, 10 & 3699.5 & 3714.5 & 15 & 740 \\
\hline Sat, 11 & 3729.4 & 3747.1 & 17.7 & 740 \\
\hline Sun, 12 & 3763.4 & 3781.2 & 17.8 & 888 \\
\hline Mon, 13 & 3806.6 & 3820.2 & 13.6 & 1154 \\
\hline
\end{tabular}

Table B. 3

Full-scale experiment dishwashing machine electrical consumption raw data

\begin{tabular}{|c|c|c|c|c|}
\hline & & $\begin{array}{l}\text { Raw electricity } \\
\text { meter reading at the } \\
\text { start of the shift } \\
(\mathrm{kWh})\end{array}$ & $\begin{array}{l}\text { Raw } \\
\text { electricity } \\
\text { meter } \\
\text { reading at the } \\
\text { end of the } \\
\text { shift }(\mathrm{kWh}) \\
\end{array}$ & $\begin{array}{l}\text { Electricity } \\
\text { consumption } \\
(\mathrm{kWh})\end{array}$ \\
\hline \multirow{5}{*}{$\begin{array}{l}\text { Trays } \\
\text { Dining }\end{array}$} & Tuesday & 94.2 & 105.1 & 10.9 \\
\hline & Wednesday & 135.8 & 147.8 & 12 \\
\hline & Thursday & 171.4 & 183.2 & 11.8 \\
\hline & Friday & 135.8 & 147.8 & 12 \\
\hline & Saturday & 229.8 & 243 & 13.2 \\
\hline \multirow{5}{*}{$\begin{array}{c}\text { Trayless } \\
\text { Dining }\end{array}$} & Tuesday & 140.9 & 150.9 & 10 \\
\hline & Wednesday & 155.1 & 166.3 & 11.2 \\
\hline & Thursday & 207.9 & 218.5 & 10.6 \\
\hline & Friday & 243.1 & 253 & 9.9 \\
\hline & Saturday & 201.6 & 214.4 & 12.8 \\
\hline
\end{tabular}


Table B. 4

Full-scale experiment water consumption raw data

\begin{tabular}{|c|l|l|l|c|}
\cline { 3 - 5 } & & $\begin{array}{l}\text { Raw } \\
\text { dishwashing } \\
\text { machine } \\
\text { water meter } \\
\text { reading at } \\
\text { the start of } \\
\text { the shift } \\
\text { (gal) }\end{array}$ & $\begin{array}{l}\text { Raw } \\
\text { dishwashing } \\
\text { machine } \\
\text { water meter } \\
\text { reading at the } \\
\text { end of the } \\
\text { shift (gal) }\end{array}$ & $\begin{array}{l}\text { Water } \\
\text { consumption } \\
\text { (gal) }\end{array}$ \\
\hline \multirow{5}{*}{ Trays Dining } & Wednesday & 185782.5 & 185985 & 202.5 \\
\cline { 2 - 6 } & Thursday & 186838 & 187063 & 225 \\
\cline { 2 - 6 } & Friday & 188001 & 188206 & 205 \\
\cline { 2 - 6 } & Saturday & 188840 & 189063 & 223 \\
\hline \multirow{5}{*}{$\begin{array}{c}\text { Trayless } \\
\text { Dining }\end{array}$} & Tuesday & 225185 & 225315 & 130 \\
\cline { 2 - 6 } & Wednesday & 226358 & 226524 & 166 \\
\cline { 2 - 6 } & Thursday & 227436 & 227605 & 169 \\
\cline { 2 - 6 } & Friday & 228665 & 228840 & 175 \\
\cline { 2 - 6 } & Saturday & 229510 & 229725 & 215 \\
\hline
\end{tabular}




\section{Appendix C: SimaPro Software Parameters Description}

Notes: The following descriptions were adopted from SimaPro Software 2011

\section{$\underline{\text { Electricity }}$}

"SimaPro Software Name: Electricity, hard coal, at power plant/DE S" (SimaPro Software 2010).

\section{$\underline{\text { Water }}$}

"SimaPro Software Name:Tap water, at user/RER S" (SimaPro Software 2010).

\section{$\underline{\text { Steam }}$}

"SimaPro Software Name:Steam, for chemical processes, at plant/RER S" (SimaPro

Software 2010).

\section{Trays and dinner plates}

"SimaPro Software Name:Glass fibre reinforced plastic, polyamide, injection moulding, at plant/RER S" (SimaPro Software 2010).

\section{$\underline{\text { Wastewater }}$}

"SimaPro Software Name:Treatment, sewage, to wastewater treatment, class 4/CH U" (SimaPro Software 2010).

\section{$\underline{\text { Food Waste }}$}

"Disposal, refinery sludge, 89.5\% water, to sanitary landfill $/ \mathrm{kg} / \mathrm{CH}$ " (SimaPro Software 2010). 


\section{Appendix D: Survey of Students Attitudes for Trayless Dining}

To ascertain student opinions regarding trayless dining in Michigan Tech residence hall dining areas, a team of students from the Green Campus Enterprise conducted a survey (approval number M0498 from the Office of Research Integrity and Compliance) at Michigan Tech in the three residential halls at Michigan Tech:

Wadsworth Hall (October 21, 2009), McNair Hall (November 11, 2009), and Douglass Houghton Hall (November 18, 2009) during the 2009 fall term dinner shift. To ensure that students were adequately notified of the survey before its occurrence, flyers specifying the time (normal dinner hours) and location (the dining hall) were circulated two days prior to the survey date. To generate further interest in the survey, a prize drawing was incorporated into the survey submission process by including detachable "tickets" on the top portion of the survey form; Michigan Tech Dining Services donated the prizes. To ensure the anonymity of those taking the survey, submissions were tabulated separately from the contact information. Both the design of the flyers and the design of the survey document were submitted to the Institutional Review Board at Michigan Technological University to obtain human subjects approval for the team's processes before the survey procedure began.

The students were asked, "Would you be supportive of instituting a trayless dining policy in the dining halls at Michigan Tech?" The students could respond by selecting from three options: 1) One day per week, 2) Seven days per week, or 3) Never. The results are shown in Table D.1. The first survey was conducted at Wadsworth Hall cafeteria, followed by McNair Hall, and then Douglas Houghton Hall (DHH).

Table D. 1

Survey results

\begin{tabular}{|c|c|c|c|c|c|c|}
\hline & $\begin{array}{c}{ }^{1} \text { Wads } \\
\text { Responders }\end{array}$ & Percent & $\begin{array}{l}{ }^{2} \text { McNair } \\
\text { Responders }\end{array}$ & Percent & $\begin{array}{c}{ }^{3} \mathrm{DHH} \\
\text { Responders }\end{array}$ & Percent \\
\hline One day/week & 106 & $29.5 \%$ & 24 & $16 \%$ & 21 & $24.1 \%$ \\
\hline $\begin{array}{l}\text { Seven days a } \\
\text { week }\end{array}$ & 88 & $24.5 \%$ & 44 & $29.3 \%$ & 33 & $37.9 \%$ \\
\hline Never & 165 & $46.0 \%$ & 88 & $54.7 \%$ & 33 & $37.9 \%$ \\
\hline
\end{tabular}


Although a significant number of students opposed implementing trayless dining, the majority of respondents in Wadsworth and DHH approved trayless dining at least one day per week. DHH is the smallest of the dining halls with food served a short distance from the dining tables so the higher percentage of students in favor of the conversion was understandable. During the survey, the students were asked for feedback and suggestions if trayless dining was implemented at Michigan Tech. The following list identifies the common comments elicited during the survey.

- Inform students before implementation

- Introduce trayless dining at the beginning of the academic year

- Make change as a gradual process from one day to seven days a week

- Make trays available upon request

- Pass on any savings to students by lowering housing costs

- Use compartmentalized trays

A large portion of students surveyed also suggested the possibility of switching to compartmentalized trays as a means of cutting down on dishes by eliminating the need for plates, while not reducing dining convenience. Mr. Hiltunen, Director of Dining Services, was not in favor of this suggestion stating that compartmentalized trays would create an overly institutionalized feel to the students' dining experiences. To explore this option further, Green Campus students suggested displaying a sample compartmentalized tray in the dining halls and polling the students on their opinion.

The Green Campus Enterprise students also contacted Amrys Mikinel of Grand Valley State University, which had recently made the switch to trayless dining. Suggestions for the conversion included the following:

- Inform the students of the reason for the change, including data on savings.

- Advertise the change rather than trying to make the change quietly.

- Make the shift at the start of the academic year before incoming freshmen have grown accustomed to dining with trays. 